\title{
Contributions of larval biology to crustacean research: a review
}

\author{
KLAUS ANGER \\ Biologische Anstalt Helgoland, Stiftung Alfred-Wegener-Institut für Polar- und Meeresforschung, \\ 27498 Helgoland, Germany \\ Tel. +49 (4725) 819348; Fax+49 (4725) 819369; e-mail: kanger@awi-bremerhaven.de
}

Received 7 March 2006; Accepted 21 April 2006

\begin{abstract}
Summary
Many aquatic crustaceans pass through a complex life cycle comprising a benthic juvenile-adult and a pelagic larval phase. In the study of aquatic ecology, meroplanktonic larvae are therefore considered as principal components of benthic-pelagic coupling processes. As a consequence of radical transitions of life style, larvae differ from conspecific adults in their ecology, behaviour, nutrition, morphology, and physiology. Ontogenetic changes of these traits, as well as carry-over effects of larval condition on postmetamorphic fitness of benthic juveniles, are subjects of the interdisciplinary field of larval biology. Larval biology is thus not only an intrinsic part of lifehistory studies, but contributes essential information also to various other biological disciplines, including the broad area of crustacean research. For economically important species, it provides critical information for the development of aquaculture techniques or for the management of sustainable fisheries. Inferring from heritable ontogenetic patterns, comparative studies of larval morphology also aid the identification of phylogenetic relationships within and among higher taxa ("Evo-Devo" perspective). On the other hand, larval traits may be modified by environmental factors, which link larval ecology to developmental biology ("Eco-Devo" approach). Patterns of larval dispersal, mortality, and recruitment are crucial for the stability of benthic populations and communities. These aspects of "supply-side ecology" have also consequences for patterns of biogeographic distribution, population connectivity, genetic diversity, and the formation of metapopulations. In addition, the spread of introduced species in recipient regions may be explained or predicted through developmental and ecophysiological traits of their larvae. In evolutionary biology, knowledge of reproductive and developmental adaptations is crucial for the understanding of limnic and terrestrial invasions by originally marine crustaceans.
\end{abstract}

Key words: Crustacea, Decapoda, life history, larval development, benthic-pelagic coupling, supplyside ecology, Evo-Devo, Eco-Devo, carry-over effects, dispersal, introduced species, adaptation, invasiveness, adaptive radiation

\section{Subjects of Larval Biology}

\section{Complex life histories}

Most benthic, but also many pelagic marine invertebrate species as well as some inhabitants of freshwater ecosystems, pass through complex life cycles (Havenhand, 1995; McEdward, 2000; Pechenik, 1999). These comprise an embryonic, a larval, and a juvenileadult phase, instead of a direct development from the egg to an adult-like juvenile. Among the bottom- 
dwelling marine invertebrate species, an indirect development through a planktonic larval phase is typically found, for example, in most cnidarians, molluscs, polychaetes, echinoderms, tunicates, and in crustaceans, which are the principal subject of this review (see Thorson, 1946, 1950). Benthic species with complex or biphasic life cycles pass through radical ontogenetic transitions of habitat and life style, implying dramatic changes in the modes of locomotion and feeding, as well as many other vital functions. Hence, successive ontogenetic stages of species with complex life histories occupy at least two different niches (for comprehensive discussion of the niche concept, see Roughgarden, 1972; recent reviews by Feldmann, 2003; Evans et al., 2005; Rundle and Nosil, 2005). An adult brachyuran crab, for instance, may be a benthic predator or scavenger, while the larvae of the same species are planktonic suspension feeders, differing greatly in habitat, locomotion, feeding, behaviour, etc. Most typical "larval" features such as swimming behaviour, or functional morphology of natatory and feeding appendages, represent stage-specific adaptations to the pelagic environment where the larvae live and develop, floating in the water column as "meroplankton" (from Greek, freely translated: "part-time plankton"), together with fully planktonic organisms ("holoplankton”).

Among the benthic Crustacea, particularly dramatic ontogenetic changes in ecology, feeding, behaviour, and functional morphology are generally found in barnacles and decapods. However, similar changes occur also in some fully pelagic life-histories. Euphausids, for instance, release their eggs that passively float in the water column, where the conspecific larvae, juveniles and adults live (see Silas and Mathew, 1977; Menshenina, 1990; Maas and Waloßek, 2001). Holopelagic life histories with a larval phase also occur in some caridean (Bauer, 2004) and dendrobranchiate shrimps (Williamson, 1982; Dall et al., 1990). In these cases, however, larvae and conspecific adults differ significantly in morphology, modes of feeding and locomotion, or predominant food sources.

It has been presumed that complex life histories are correlated with longevity, however, this may not be a general relationship, or at least the available evidence is statistically weak (Eckert, 2003; see Fig. 1a, A). The existence of a meroplanktonic larval phase (regardless if long or short) appears to stabilize benthic populations, reducing the variability of population density (Fig. 1a, B). Also on evolutionary time scales, genetic exchange through larval dispersal has probably a stabilizing effect, resulting in a prolonged temporal range. At least, this has been shown for taxa where the fossil record is sufficiently complete, for instance in gastropods (Jablonski, 1982; Scheltema, 1986; see Fig. 1b).

\section{What makes up a larva?}

Our examples of complex life cycles show that the decisive criterion for the larval nature of an early ontogenetic stage is not its planktonic life style per se, but the occurrence of unique "larval" traits (Williamson, 1982; Strathmann, 1993a; Anger, 2001). These are absent in embryos (regardless whether the eggs are attached to the mother animal or spawned freely), appear in an actively swimming intermediate ontogenetic period (the larval phase), and are lost at metamorphosis to the first juvenile stage (regardless if this is benthic or pelagic). In conclusion, a "larva" may be defined as a free-living early developmental stage, which differs in specific traits from both earlier and later life-history stages of the same species. These traits comprise mainly morphological, but also behavioural features related to feeding and locomotion, representing adaptations to a planktonic life style and permitting the exploitation of resources other than those the adults rely on.

This definition implies that a larva cannot be recognized through the lack or incomplete development of adult traits, but through an exclusive, ontogenetically transitory presence of stage-specific "larval" traits. These may be present in functional morphology of locomotion and feeding, in moulting and growth, and inherent in physiology and biochemical processes. A juvenile, by contrast, is similar to the conspecific adults, although some species-specific traits may still be rudimentary, non-functional, or completely lacking (e.g. the gonopods of brachyuran crabs). The juvenile phase is thus defined through an underdeveloped condition of adult traits, which are gradually completed during growth and maturation. Although conspicuous morphological and physiological changes may occur later, especially at the onset of sexual maturity (for instance at the "puberty moult" of majid crabs; Hartnoll, 2001; Ernst et al., 2005), these changes are hardly comparable with the dramatic transitions typically associated with larval development and metamorphosis.

Transitorily occurring "larval" traits are the principal subjects of the large and by nature interdisciplinary field of larval biology. Concentrating on examples from the Decapoda, I will, in this review, briefly characterize principal types of crustacean larvae, show difficulties in their classification, identify major limitations in our knowledge of larval biology, and discuss achievements that have been, or may become, major contributions to other disciplines within the broad area of crustacean research.

\section{Principal Types of Crustacean Larvae}

Williamson (1982) gave a comprehensive review of larval types in the Crustacea and Anger (2001) provided 


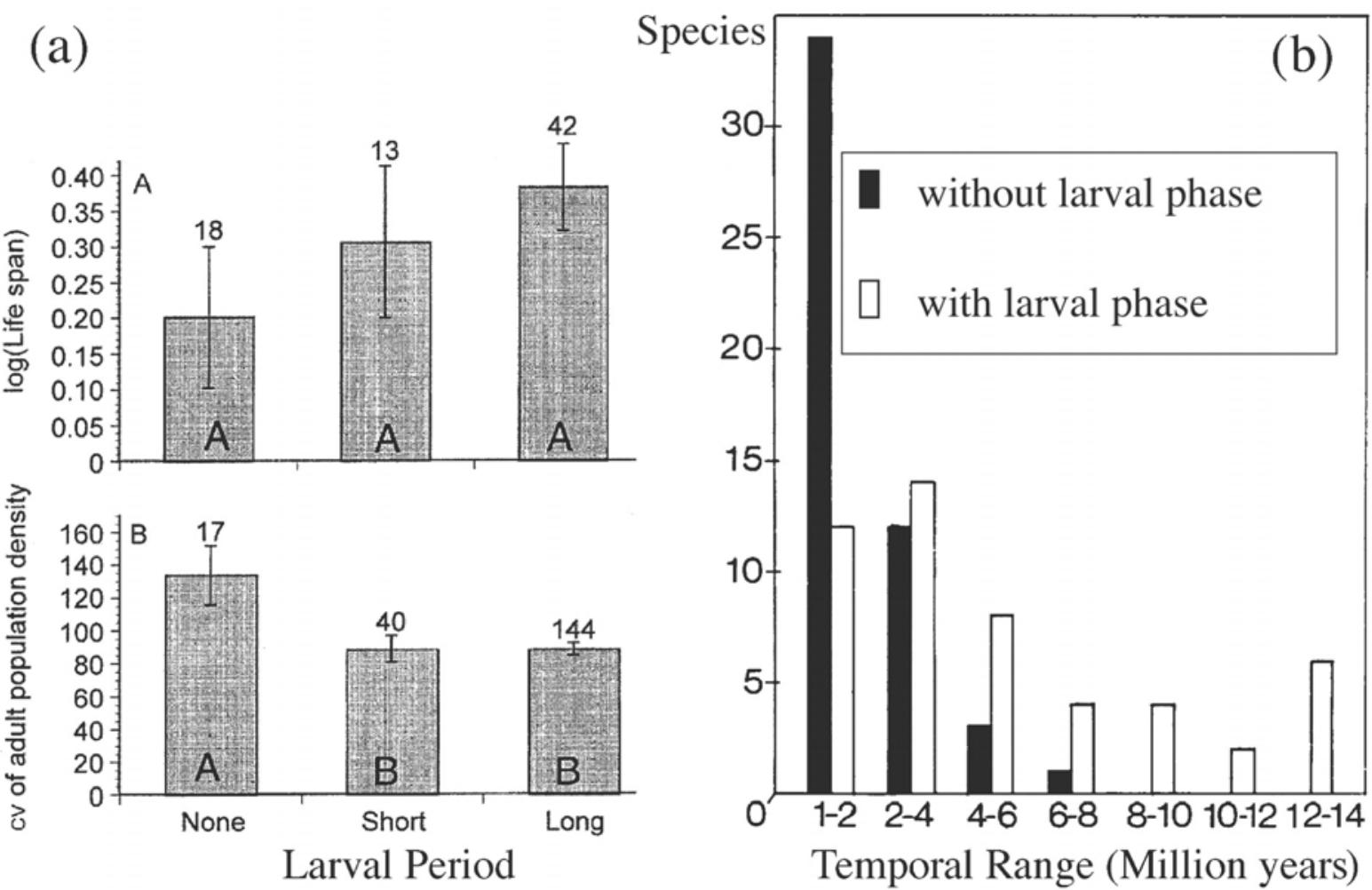

Fig. 1. (a) Relationship between length of the larval period and: A, estimated adult life span (log years; letters above bars = number of species; no statistically significant differences); B, coefficient of variability (CV) of adult population density (numbers above bars = numbers of population time series); populations with no planktonic larval period had significantly greater CV than populations with a (short or long) larval period; (b) relationship between mode of development and temporal range of Late Creataceous gastropods; (a) after Eckert (2003); (b) after Jablonski (1982).

an illustrated overview of the principal forms. Therefore only a brief definition of the most common larval types will be presented in order to exemplifying and further clarifying the concept of a crustacean "larva".

\section{The nauplius}

Among the Crustacea, the most primitive, most wide-spread, and best known example of a larval form is the nauplius sensu lato (Dahms, 2000; Scholtz, 2000; Waloßek and Maas, 2005; see also below, section "EvoDevo"). It has only three pairs of cephalic but no thoracic appendages, namely the antennules (first antennae), the antennae (second antennae), and the mandibles (Fig. 2a). These larval limbs have primarily natatory functions. During later stages of the life cycle, they become sensory and food-processing organs, respectively. Nauplius stages are found in various benthic crustacean taxa such the as cirripedes and dendrobranchiate shrimps, but also in fully pelagic forms including the copepods and euphausids. When additional body segments (but no additional appendages) are added, the stage is commonly referred to as a metanauplius (cf. Fig. 5b).

\section{The zoea}

In the "primitive" Decapoda (the Dendrobranchiata; see below, section "Evo-Devo"), the nauplius phase is followed by a zoeal phase, which includes several protozoeal and mysis stages (Figs. 2b, c). By contrast, for all "higher" Decapoda (the Pleocymata) the zoea is the characteristic hatching stage (Fig. 2d). A zoea is morphologically more advanced than a nauplius, swimming with functional thoracic appendages. Its cephalic appendages have typically lost their natatory functions, being involved in the perception and processing of food (exception: the protozoea of the Dendrobranchiata; Fig. 2b). In this respect, zoeae resemble the juvenile and adult condition. However, the pleonal appendages are still completely absent or rudimentary and non-functional. The aberrant larval form found in palinurid and scyllarid lobsters, the phyllosoma, belongs, according to functional morphology, to the zoea type (Williamson, 1982).

\section{The decapodid or megalopa}

The zoeal phase is followed by a decapodid or megalopa stage (Williamson, 1982; Anger, 2001), often 
(a)
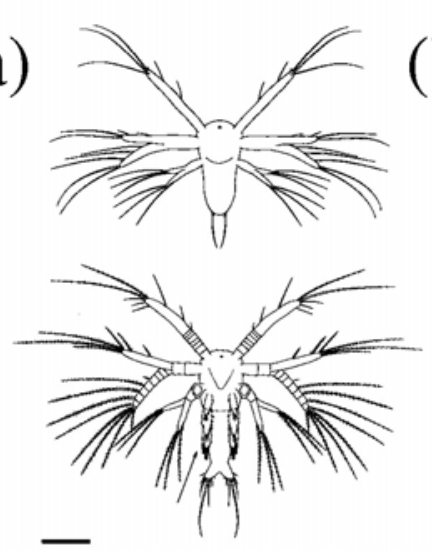

$0.2 \mathrm{~mm}$

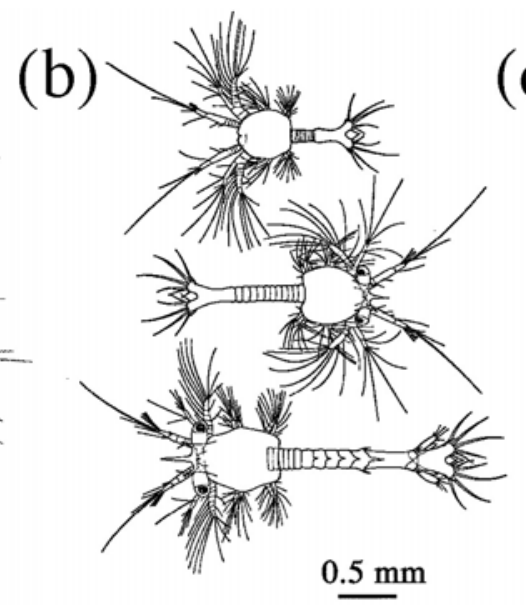

(c)
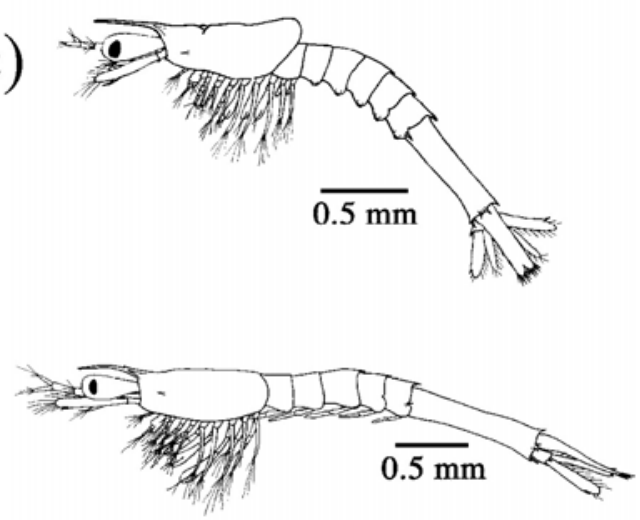

(d)
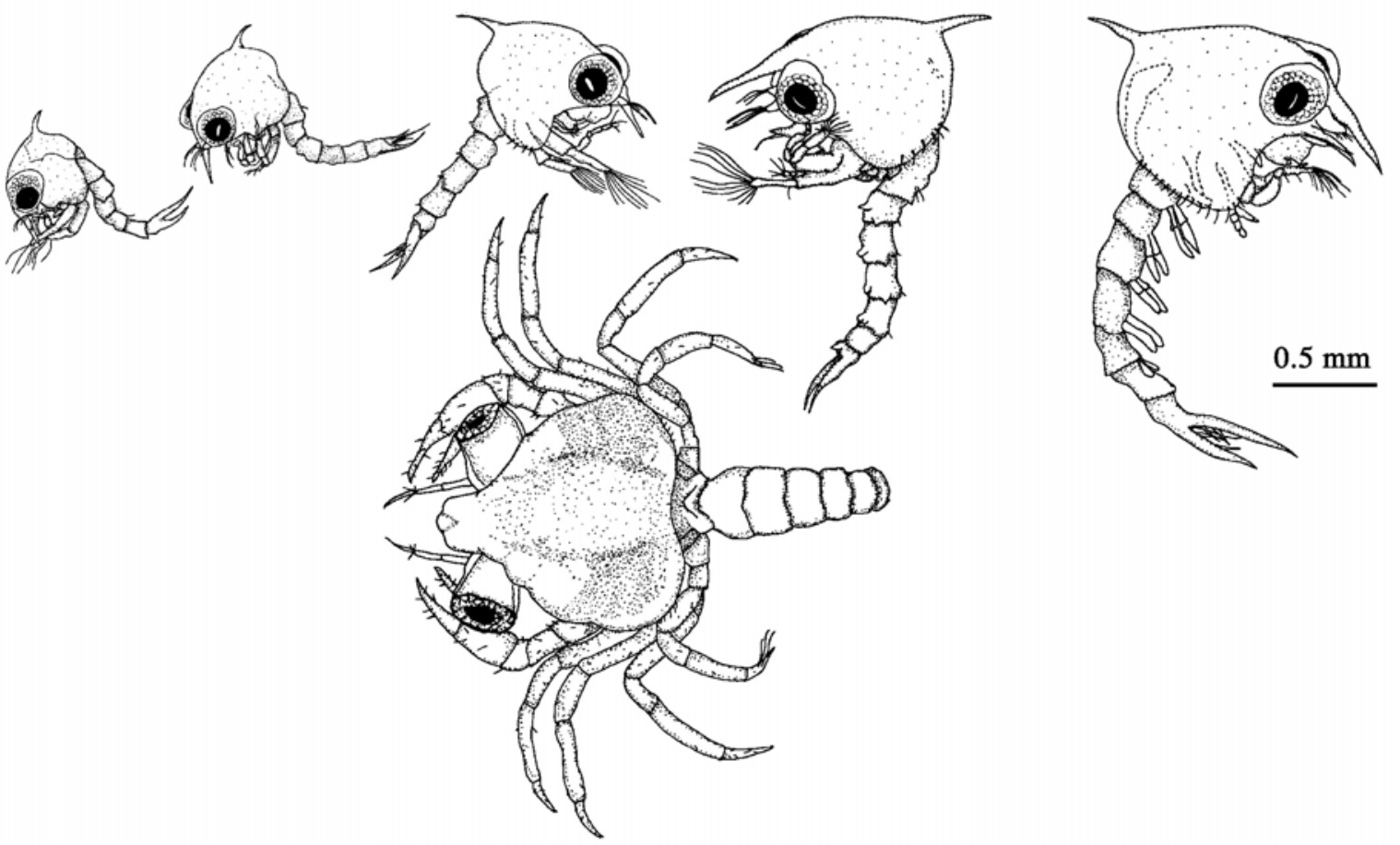

Fig. 2. Some typical crustacean larvae. (a-c) Larvae of dendrobranchiate shrimps: a, Farfantepenaeus brasiliensis, nauplius stages I and V; b, Penaeus esculentus, protozoeal stages I-III; c, F. brasiliensis, mysis stages I and III; (d) larvae of a brachyuran crab, Uca thayeri, zoeal stages I-V, megalopa; a, c after Dobkin (1961); b, after Fielder et al. (1975); d, after Anger et al. (1990).

referred to ambiguously as a "postlarva” (Felder et al., 1985). It is characterized by functional pleonal appendages, the pleopods. While decapodids are ecologically, behaviourally and morphologically similar to the (mostly benthic) juveniles, they can still be considered as larval stages, at least in reptant decapods (i.e., the Astacidea, Thalassinidea, Anomura, and Brachyura). Similar to juveniles and adults, they can use the pereiopods for walking but will also readily swim using the pleopods.

\section{Problems of larval staging}

For some crustacean taxa, the classification of larval stages is indefinitive, because they are lacking a true metamorphosis. In the extant Anostraca, for instance, the antennules and antennae are still used for swimming until the latest phase of development, when all thoracopods already operate as filter limbs (Waloßek and Müller, 1998). Among the Decapoda, a continuous pattern of change in functional morphology is particularly well documented for caridean shrimps, which 


\section{(a)}

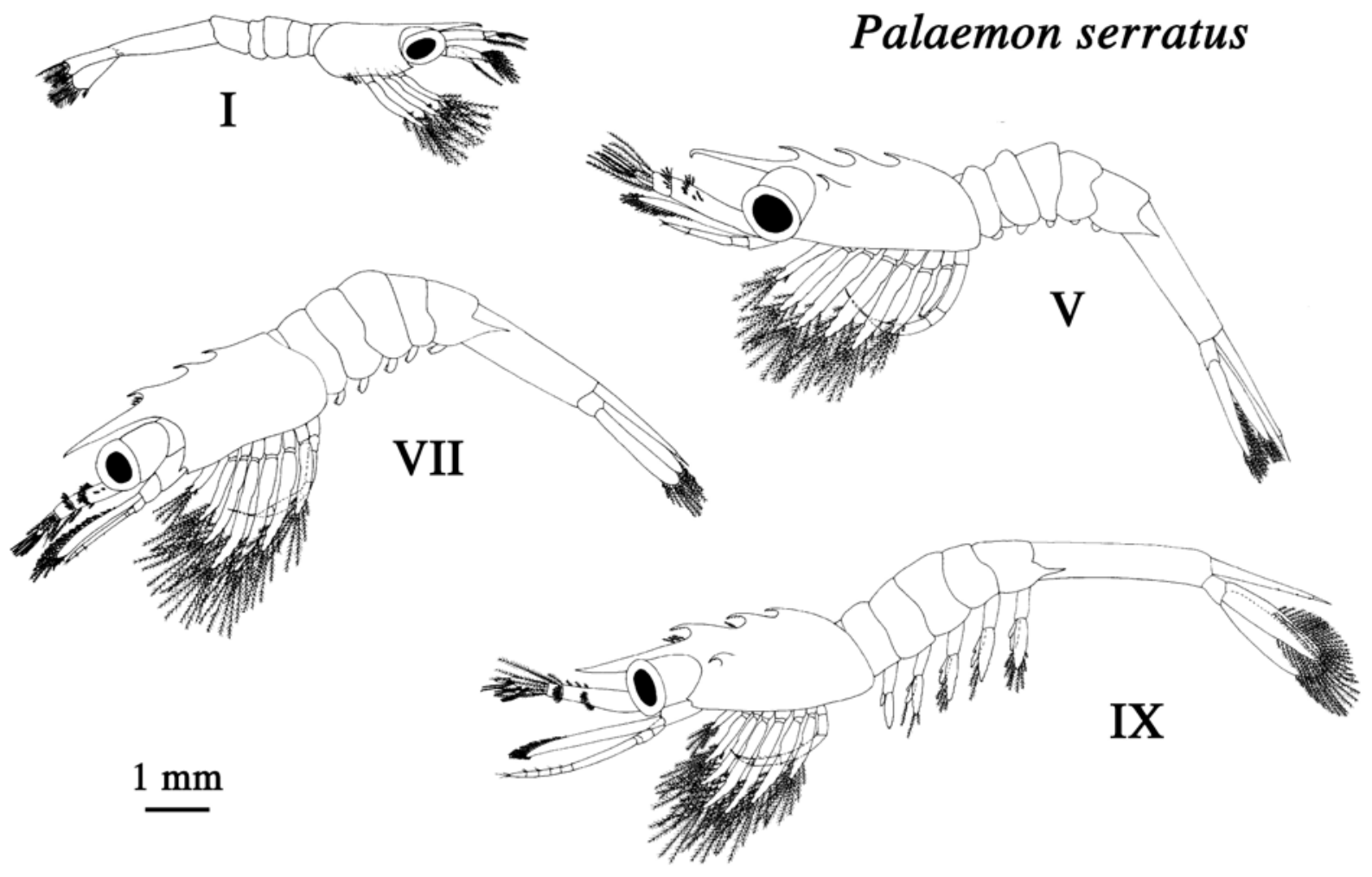

(b)
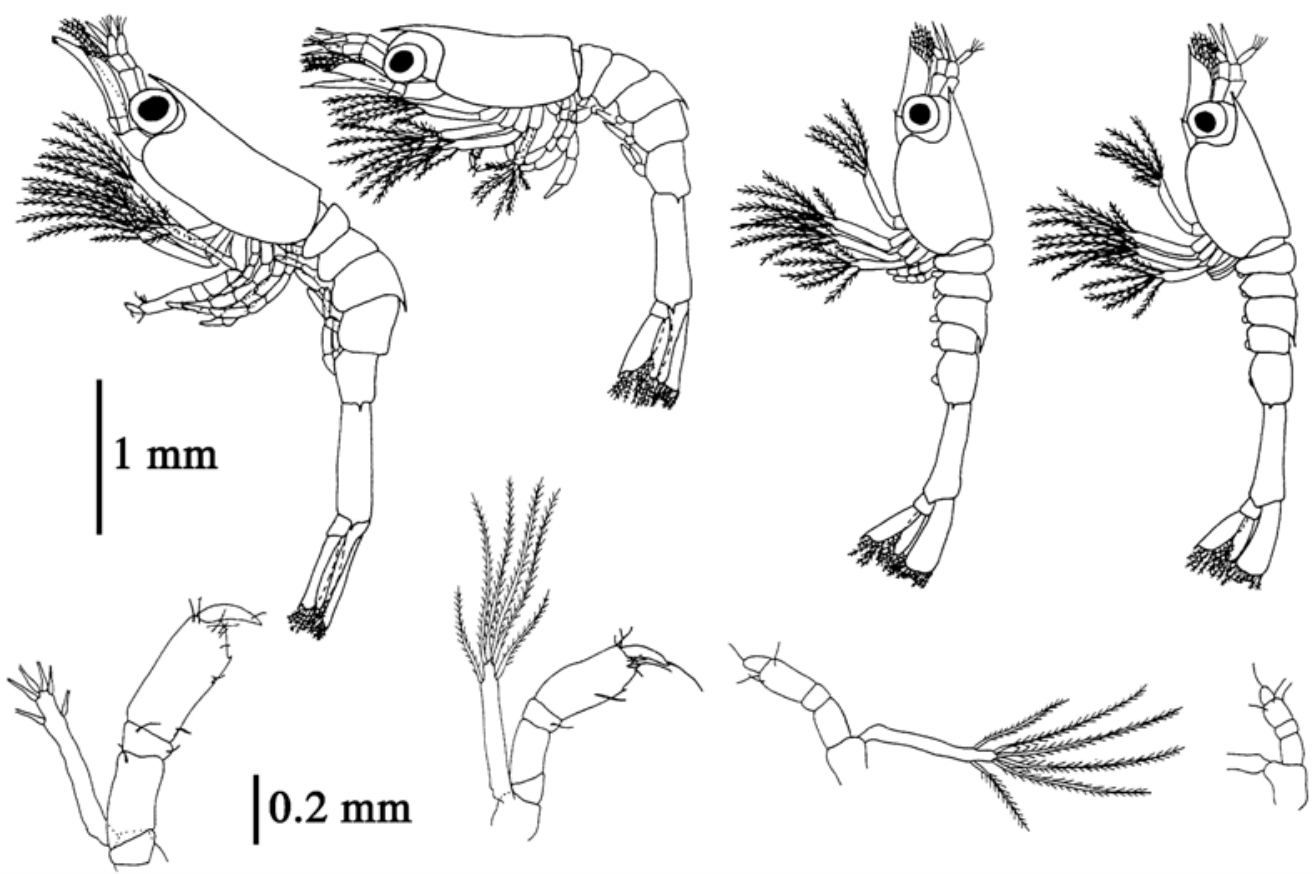

Fig. 3. Hemimetabolous (gradual) development and morphological variability in caridean shrimp larvae. (a) Selected larval stages (I, V, VII, IX) of Palaemon serratus (after Fincham, 1983); (b) variability in body size, pleopod formation, and morphology of pereiopod 1 in the zoea-IV stage of Crangon crangon (from Linck, 1995). 
are used here as an example. Firstly, there are some taxa — namely the primitive anchialine Procarididae and the pelagic Oplophoridae and Pasiphaeidae - that retain pereiopodal exopods throughout the adult phase (Bauer, 2004). Although their larvae are largely unknown, it may be assumed that they are characterized by a lack of particular adult features rather than by the presence of unique larval traits, i.e. they may be "juvenile-like" rather than representing true larval stages.

Most carideans show a great deal of intraspecific variability in the number and morphology of their larval stages, and morphological and behavioural transitions between successive stages are gradual rather than metamorphic, resembling the developmental patterns of hemimetabolous insects (Fig. 3a). The natatory exopods of the pereiopods, for example, may persist not only from the first to the last planktonic zoeal stage, but also throughout the subsequent semibenthic (also termed demersal or bentho-pelagic) decapodid phase. Over successive moults, the locomotory functions are, in the decapodid stages, increasingly taken over by the growing and differentiating pleopods, while the pereiopodal exopods (a zoeal character) are only gradually reduced. Similarly, the pleopods (a character that distinguishes a decapodid from a zoea) retain their natatory function from the first decapodid throughout the subsequent benthic juvenile and adult life-history phase. Although the juveniles and adults use mainly their pereiopods as walking legs, the pleopods remain important too, allowing for intermittent swimming above the ground. In conclusion, the end of the larval phase in the caridean life cycle may be defined theoretically by the final loss of the natatory function of the pereiopodal exopods. However, even this important developmental change often occurs only gradually rather than as a metamorphosis. Small and functionally insignificant but still visible vestiges of the exopods may persist on the bases of the walking legs and disappear gradually over several juvenile moults. These gradual shifts in functional morphology are accompanied by equally gradual and overlapping transitions of behaviour, from fully pelagic zoeal swimming to a mixture of near-bottom swimming and crawling during the decapodid stages, and eventually to walking on benthic surfaces in late decapodids and early juveniles. As a consequence of these hemimetabolous developmental patterns in caridean shrimps, it is sometimes impossible to clearly distinguish successive larval types (e.g., late zoeal stages vs. early decapodids), and also between late larvae (decapodids) and early juveniles.

There is an additional complication in the staging of caridean shrimp larvae. The morphology of a given "instar" (or "numerical stage", defined by the number of larval moults) varies among hatches, individuals, and rearing conditions (Anger, 2001). Variability in the zoea-IV stage of the shrimp Crangon crangon is shown here as an example (Fig. 3b). While some individuals have in this instar only rudimentary pleopod buds developed, others show fully developed and functional pleopods (i.e., reaching the condition of a decapodid). Similarly, after the same number of moults, the natatory exopods of the pereiopods may show different degrees of morphological development, varying gradually from small and hardly differentiated limb buds to functional swimming appendages (for more comprehensive review of the various degrees and patterns of abbreviation or extension occurring in the larval development of decapod crustaceans, see Clark, 2000, 2005).

\section{Where Larval Biology is an "Underdeveloped Field” within Crustacean Research}

Before citing examples of significant contributions of larval biology to other fields of crustacean research, I will first exemplify issues where larval biology has contributed little or nothing, but profited much from investigations on juvenile and adult crustaceans. This is due, in part, to the fact that larval biology is a relatively new and therefore lesser developed life science discipline. Even the very existence of larval crustaceans was recognized less than two centuries ago (Ingle, 1998; Anger, 2001). When we look at physiological and biochemical aspects, we must admit that we know very little about larvae as compared to the broad and detailed understanding of the biology of juvenile and adult lifehistory stages of crustaceans. As a consequence, we are still often forced to extrapolate presumable, but actually unknown, larval traits from known adult features.

\section{Inherent constraints and limitations of larval biology}

Besides historical reasons, there are several major technical problems that have constrained the progress of larval biology within the large field of crustacean biology:

1. Larvae are very small compared to adults. The adults of a fairly large species of crab such as Cancer pagurus, for instance, can reach more than $20 \mathrm{~cm}$ carapace width, while the early zoeae measure less than $0.5 \mathrm{~mm}$, i.e. they differ by a factor of several hundred. The discrepancy in organic biomass of an adult and a larva (in C. pagurus several hundred grams vs. a few micrograms of dry mass or carbon content per zoea) may exceed even 7-8 orders of magnitude. As a consequence, the minimal sample size required for biochemical analyses of biomass composition, or the technical limits for measurements of physiological rates 
such as oxygen consumption or nitrogen excretion, render physiological and biochemical studies of individual larvae in most cases impossible. Exceptions occur only in taxa with uncommonly large larvae, for instance in clawed lobsters and lithodid crabs (e.g. Lovrich et al., 2003; Rotllant et al., 2004). In other taxa, measurements are normally only possible with pooled samples comprising numerous larvae with homogeneous characteristics (ideally, not only with identical taxonomic origin and developmental stage, but also with the same age within the moulting cycle of a given larval stage and same nutritional history, etc.). For juvenile and adult crustaceans, by contrast, such studies can be easily carried out on single individuals, also on individual organs and tissues.

2. In laboratory studies, the production of sufficient quantities of homogeneous larval materials requires tedious and time-consuming rearing techniques. Moreover, artificial rearing conditions may incur unrecognised laboratory artifacts, which are difficult to identify. For example, it has remained a controversial issue among larval biologists, whether the prezoea really exists as a true larval stage (regularly occurring also in nature) or represents a mere laboratory artifact (see Konishi and Quintana, 1987; Williamson, 1982; recent review in Anger, 2001). The available evidence suggests that it represents the latest embryonic rather than the earliest larval stage (Williamson, 1982), which may be delayed under conditions of stress. This implies, however, that hatching as a prezoea may occur also under unfavourable conditions in nature. More obvious cases of laboratory artifacts have been observed in developmental patterns of larval growth and biochemical composition, where artificial culture conditions of unlimited feeding and restricted space for swimming activity can cause "domestication effects" such as fattening and reduced development of muscle proteins (for references, see Anger, 2001).

3. Samples taken from the field contain rarely larvae of equal taxonomic status and developmental stage, and there is no information concerning the time of their hatching or moulting, or on previous feeding or environmental conditions.

\section{Example: the moulting cycle}

In the Arthropoda, development and growth are closely related to the recurrent shedding and replacement of the culticle. Since Drach's (1939) classical account of cyclical changes in the structure of the integument of Cancer pagurus, moult-cycle related processes have been subjects of innumerable histological, ultrastructural, biochemical and physiological investigations (for recent review, see Charmantier-
Daures and Vernet, 2004). It has been known for more than a century that those cyclic phenomena are hormonally controlled by an antagonistic system of “compensatory regulation” (Zeleny, 1905) or antagonistic factors (Chang et al., 2001). These consist of moult-stimulating ecdysteroids (in adult Decapoda produced in the $\mathrm{Y}$ organs) and moult-inhibiting neuropeptides produced and stored in the endocrine $\mathrm{X}$-organsinus-gland complex of the eye stalks. However, it is less understood if the same system, or a simplified version thereof, is functional also in crustacean larvae. In addition, juvenoid hormones seem to be involved in the control of larval moulting and development $(\mathrm{Mu}$ and Leblanc, 2004; McKenney, 2005; Tuberty and McKenney, 2005), and chemical triggers from the environment can also accelerate or delay the timing of metamorphosis, i.e. of larval moulting (see e.g., Castro, 1978; cf. section on habitat choice and control of settlement, below). Compared to larval crustaceans, the physiology of larval insects is much better understood (cf. Nijhout, 1999; Chang et al., 2001), because the latter present less technical difficulties and because many studies have been directed towards economical needs, e.g. agricultural pest control.

The few investigations that have been published so far on the moulting cycle of crustacean larvae suggest that it is controlled by a similar hormonal system as in the adults (Chang and Bruce, 1981; Spindler and Anger, 1986; Webster and Dircksen, 1991). However, available data are less detailed and less comprehensive compared to those obtained from adult crustaceans. This discrepancy includes basic studies of structural changes. Drach (1939) used simple histological methods to elaborate a classification of moult-cycle related changes in the cuticle of adult crabs. By comparison, electronmicroscopical techniques are needed to study even basic changes of the thin and less complex integument of crustacean larvae (Christiansen and Costlow, 1982).

Studies of larvae suffer also from a low temporal resolution of measurements, because their moulting cycles are normally much shorter than in juvenile and adult crustaceans. For an accurate recognition in the timing of microscopical observations or physiological measurements, frequent sampling within the moulting cycle is required. Each batch of larvae should therefore exclusively contain individuals that have simultaneously passed through the preceding ecdysis, so that their "age" within each moulting cycle remains the same. Since there is always variability among sibling larvae in the timing of ecdyses and in the duration of successive moulting cycles (Spindler and Anger, 1986), this requirement can be met only with tedious individual rearing techniques, where the moulting history is individually recorded. In larvae that are randomly 
sampled from a communal rearing tank, by contrast, the precise time within the moulting cycle is individually variable and basically unknown (except for the first larval stage, if hatching occurred simultaneously). As a consequence of this "noise" in data obtained from analyses of mass-reared larvae, temporal series of physiological measurements, e.g. changes in ecdysteroid titers, may show only an approximate cyclic pattern, preventing a precise correlation of hormonal peaks at each stage and substage of the moulting cycle (Chang and Bruce, 1981).

Mainly due to such technical constraints, larval biologists have not studied the moulting cycle in detail, leaving us with the simplistic assumption that larvae may be, at least in physiological and biochemical aspects, mere miniature or "primitive" editions of adult crustaceans. However, it is likely that there are significant changes in the system of hormonal control of the moulting cycle and in other key processes, when major organs and tissues appear and become successively functional during the course of larval development. A detailed knowledge of the ontogeny of the moulting cycle should thus contribute to a more integral understanding of the physiology of crustacean growth and development.

Similar technical constraints also apply to the study of moult-cycle related endocrine control systems and to many other physiological and biochemical aspects including larval metabolism, growth, and osmoregulation. Even if some analytical problems associated with the minimally necessary sample size can be resolved, e.g. by means of molecular techniques, it will remain difficult to study larvae with a similar precision as is possible for large adult crustaceans, especially with respect to single organs or tissues. Major contributions to the understanding of basic physiological mechanisms may also in the future primarily originate from studies on adult rather than larval crustaceans. However, in spite of these serious inherent constraints for larval biology, future comparative studies of larval traits remain highly rewarding, not only as integral parts of complete life-history investigations, but also because they have far-reaching implications for the understanding of the adaptational basis of ecological and geographic-climatic distribution patterns, lifehistory evolution and speciation, and evolutionary theories.

The following sections will demonstrate with selected examples that larval biology, although retarded in some disciplines, fulfills a lead function in other fields within crustacean research. Reflecting both the available literature and the author's expertise, this review will largely concentrate on the Decapoda, but include also examples from barnacles and other "lower" crustaceans. Based on a previous, more comprehensive treatise of larval biology (Anger, 2001), emphasis is given here on the most recent published information, and where numerous references to older works may be found.

\section{The Primary Approach: Larvae in Life-History Studies}

The first and most basic contribution of larval biology to crustacean research has been the description of larvae as integral parts of individual life histories, showing primarily the ontogeny of species-specific morphological traits (Figs. 2, 3). The knowledge of the complete larval development of a species is also a prerequisite for the taxonomic identification and staging of larvae from field samples, and thus for studies of larval ecology, behaviour, dispersal and recruitment. All these aspects of larval biology have important implications for population dynamics, community ecology, biogeography and the invasiveness of introduced species (see sections below). For commercially exploited crustaceans (for instance, lobsters, penaeid, pandalid, and palaemonid shrimps, or cancrid, portunid, and lithodid crabs), basic information from larval biology is highly important for the development of economically feasible aquaculture techniques, or for sustainable fisheries management. Numerous examples can regularly be found in journals dedicated to applied aspects of crustacean biology, e.g. Aquaculture, Aquaculture Research, or Fisheries Research.

Considering the pivotal importance of larval biology within crustacean research, it is remarkable that the very existence of a larval phase within the life cycles of crustaceans was discovered only in the early 19th century (e.g. Thompson, 1828). Even thereafter, the larval nature of some marine planktonic organisms, which had previously been assigned to own "genera" such as Zoea Bosc 1802 or Megalopa Leach 1817, remained for an extended period an issue of controversial debate, until it was gradually acknowledged by the scientific community that these were larval forms (for detailed historical accounts and earlier references see Gurney, 1939; Rice, 1993; Ingle, 1998; Anger, 2001).

Throughout the 19th and the first half of the 20th century, most morphological descriptions of larval stages were based on larvae collected from the field. This left often considerable doubts as to the true taxonomic identity or the completeness of developmental series that had been reconstructed from plankton samples, sometimes combined with observations from rearing attempts that succeeded mostly through only one or two larval moults. In addition, mother animals were 
sometimes misidentified or mislabelled, and no reference specimens were stored in a museum. This shows how important it is to deposit voucher materials that can later be checked whenever necessary. Examples for doubtful larval descriptions are compiled in comprehensive reviews such as Williamson (1982), Clark et al. (1998a) and Ingle (1998).

Larval descriptions have become much more reliable during the past four or five decades, since an increasing proportion of studies has been based on the cultivation of larvae obtained from ovigerous females with known taxonomic identities (Rice, 1993; Anger, 2001). Moreover, standards for precise morphological descriptions have been greatly enhanced (Rice, 1979; Clark et al., 1998a). Larval rearing under controlled conditions in the laboratory is now the predominant approach, allowing also for ecophysiological, behavioural, nutritional, and many other kinds of biological studies.

\section{Evo-Devo: Larvae in Crustacean Phylogeny}

\section{Phylogenetic implications of larval morphology and developmental patterns}

Far beyond the scope of basically descriptive lifecycle studies of individual species, larval characteristics were soon recognised as a significant new source of independent information for the analysis of phylogenetic relationships. The earliest example may be that of H. Milne Edwards (1834) who placed a dromiid crab with a brachyuran-like adult appearance in the Anomura, because its larvae resembled those of an anomuran rather than a brachyuran crab. Also Müller's (1864) book "Für Darwin" should be mentioned in this context and, naturally, Haeckel's (1866) “Generelle Morphologie der Organismen”, where the latter author speculated that ontogeny (especially late embryogenesis) recapulated phylogenetic changes in the adult body plan (the so-called "biogenetic law”). Haeckel's hypothesis provided a stimulus for subsequent generations of researchers, although Haeckel himself modified and clarified it repeatedly to accommodate the various exceptions to this apparent concept. Also later analyses based on much broader morphological, ecological and distributional evidence, suggested that many larval features actually represented secondary adaptations to larval habitat (Hall and Wake, 1999). Haeckel's approach, i.e. a combination of evolutionary and developmental biology, has recently again assumed importance, as what is now commonly known as "Evolutionary Developmental Biology" or briefly "EvoDevo” (see Gilbert, 2001; Hoßfeld and Olsson, 2003; Scholtz, 2003).
Since Haeckel's time, characteristics of larval morphology and developmental sequences of successive stages have frequently been used as criteria to unravel phylogenetic relationships among crustacean taxa (Williamson, 1982; Scholtz, 2003). This approach has been used for intrageneric comparisons of closely related species, for making analyses of relationships between higher crustacean taxa or between the Crustacea and other arthropod groups (Scholtz, 2003), or yet higher taxonomic levels (Halanych, 2004). As Martin and Davis (2001) wrote in their synthesis of crustacean taxonomy, "for many groups of crustaceans, a study of systematic relationships is a study of larvae, as these are often the only characters, or the best characters, that we know." From Darwin's time until recently the study of cirripede phylogeny has been based upon comparative larval morphology. That the highly modified parasitic rhizocephalans were crustaceans was revealed only by their larval features, namely the cirripede-type nauplius, or a cypris larva for those families in which the naupliar phase has been supressed (Fig. 4); Chan et al., 2005; for review, see Høeg, 1995; Waloßek et al., 1996).

\section{The special role of the nauplius}

The nauplius stage is generally considered the most ancestral and universal larval form in the development of the Crustacea (Dahms, 2000; Scholtz, 2000). It had already occurred in the most primitive or "stem-line" crustaceans of the upper Cambrian (Fig. 5; for review, see Waloßek and Müller, 1998). Numerous fossils discovered in the famous "Orsten" marl deposits from Sweden in some cases even allowed the reconstruction of complete larval sequences (e.g. Waloßek, 1993). These revealed not only the ontogeny of individual fossil species, but contributed significantly also to the understanding of crustacean and arthropod phylogeny in general (Waloßek and Maas, 2005, and previous papers cited therein).

A nauplius stage can be recognised also in crustacean groups that have completely omitted a free-living larval phase, e.g. the Peracarida or, among the Decapoda, crayfish and freshwater crabs. In these cases, it is represented as a stage of the embryonic development that is passed within the egg membrane, identifiable only with histological or other microscopical techniques (e.g. Beltz et al., 1992). Due to its fundamental morphology and universal appearance among the Crustacea, it may be used for the definition of this arthropod taxon (Waloßek and Müller, 1990), or conversely, for excluding from the Crustacea other taxa that are without this stage (e.g. Waloßek and Müller, 1997, 1998). 
(a)

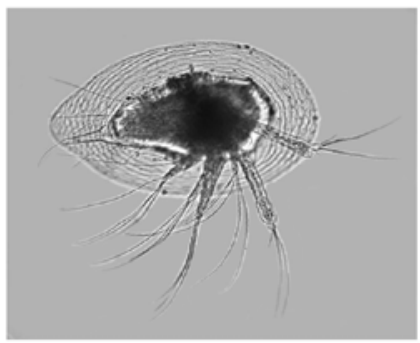

(b)

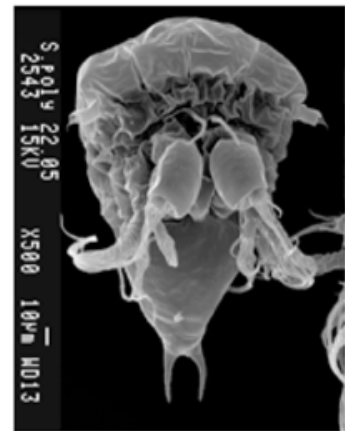

(c)

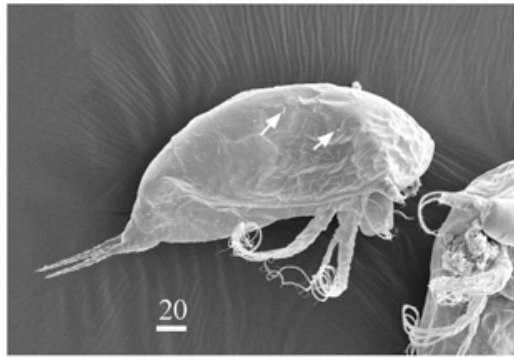

(d)

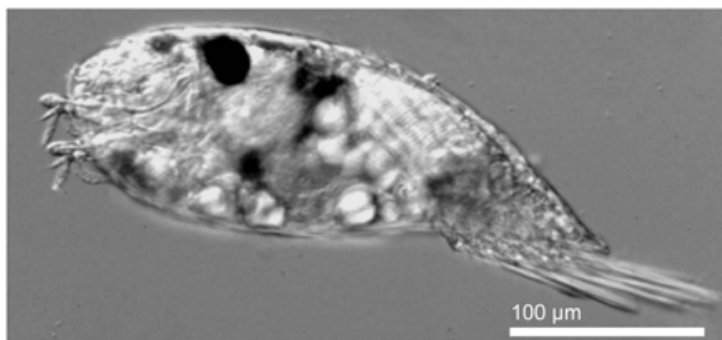

(e)

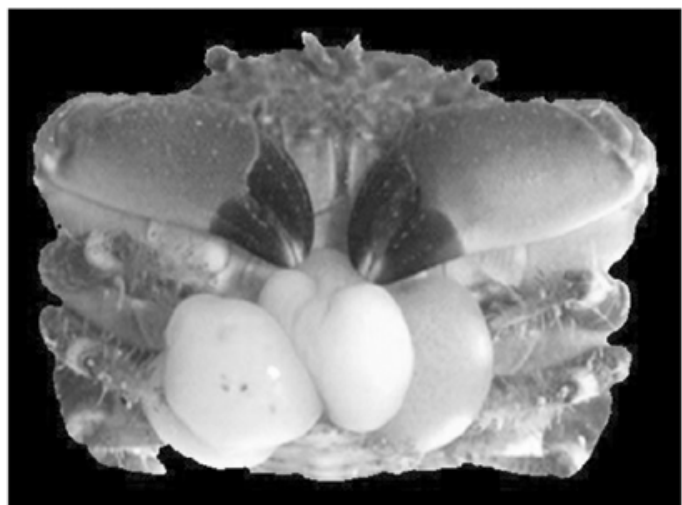

Fig. 4. Parasitic barnacles (Rhizocephala). (a-c) Nauplius larvae: a, Peltogaster paguri; b, Sacculina polygenea; c, S. sinensis; (d) cyprid of S. carcini; (e) three mature externae of S. sinensis emerging from the abdomen of a brachyuran crab, Leptodius exaratus. Photos: courtesy Dr. Jens Høeg, Copenhagen (a, b, d), Dr. B. Kwok Kan Chan, Hong Kong (c, e).
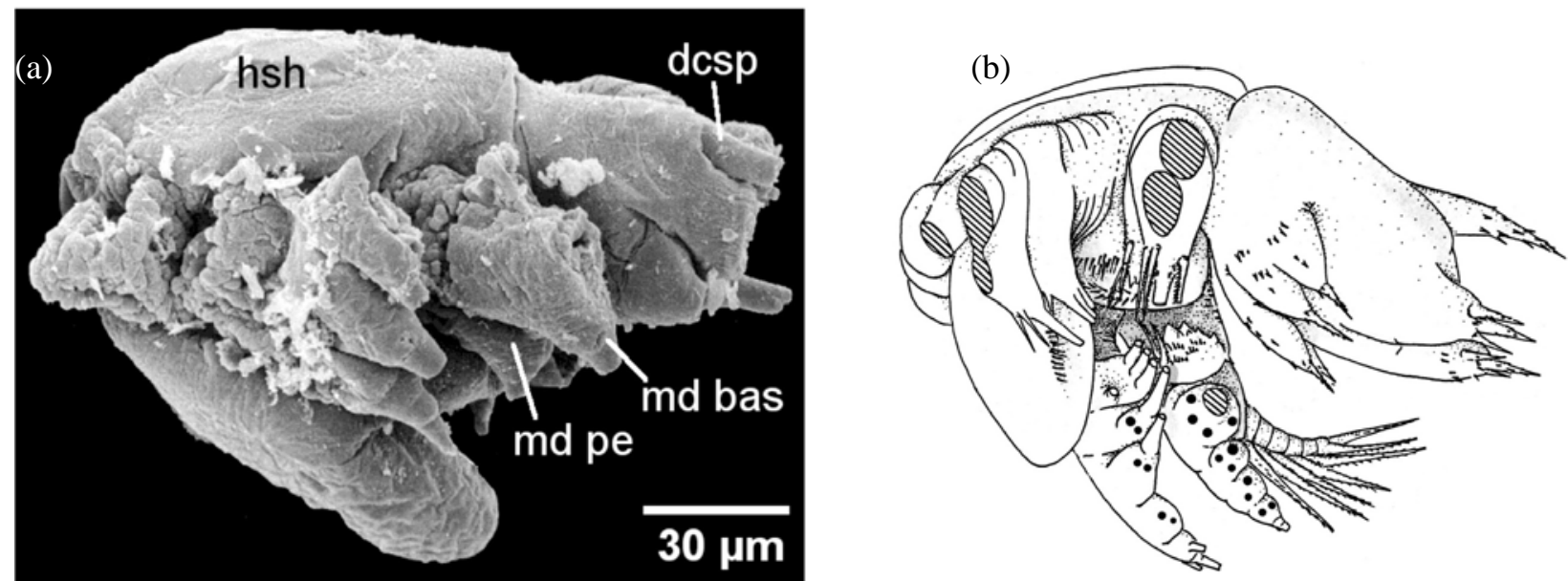

Fig. 5. Fossil nauplius larva (“orthonauplius”; for terminology, see Waloßek and Maas, 2005) of a branchiopod eucrustracean, Rehbachiella kinnekullensis Müller, 1983 from the Upper Cambrian “Orsten” formation; lateral view; (a) hatching stage; limbs broken off distally; dcsp, dorsocaudal spine; hsh, head shield; md bas, basipod of mandible; md pe, proximal endite of mandible; (b) third larval stage, metanauplius II; modified, after Waloßek (1993).

\section{Phylogenetic evidence from zoeae and megalopae}

Besides the nauplius, other larval forms have been found useful for phylogenetic analyses. The zoea, for instance, has received particular attention at various taxonomic levels within the Brachyura, mostly within families (see Rice, 1980, 1981, 1983; Marques and Pohle, 1995, 1998, 2003; Pohle and Marques, 1998, 2000; Ng and Clark, 2000a, b; Clark, 2000; Santana et 
al., 2004). In some cases, information from larval morphology showed that adult characters can be misleading (e.g., Ng and Clark, 2000a, b). Similarly, the morphology of the megalopa stage may indicate phylogenetic relationships within or between brachyuran families (Martin, 1988; Rice, 1988).

Among the various larval traits studied for phylogenetic analyses, the relative timing of appearance of particular setae within a developmental sequence, their rate of development, and the expression of segmental articulations of particular appendages have been used as comparative criteria (Clark, 2000, 2005). Changes in these developmental patterns may occur due to three major heterochronic mechanisms, termed postdisplacement, predisplacement and acceleration, often associated with an abbreviation of the zoeal phase (for review of abbreviated larval developments, see Rabalais and Gore, 1985; Clark, 2005). Besides particular setae and segments of appendages, the morphology of the developing gills in the larval stages is considered a phylogenetically significant trait (Hong, 1988; Pohle and Marques, 1998).

\section{The phylogeny of the Decapoda}

Larval traits may be used to characterize presumed monophyletic groups, or to exclude a particular taxon from a group (see Ng and Clark, 2000a, b; Ko et al., 2004). Beyond systematic considerations, the tentative classification of single or combined traits as ancestral or derived, together with developmental changes of such traits, allows a hypothetical inferrence of evolutionary ancestry or descent within a group. One of the most important contributions that larval biology has made to crustacean phylogeny is the re-evaluation, during the past three decades, of the systemic classification of the Decapoda (see Bauer, 2004 for recent review). The old system, accepted for more than a century, reflected the long-time dominance of adult characters in taxonomy. It accommodated all shrimp-like decapods in one taxon, the Natantia, and all crab- and lobster-like forms in another, the Reptantia (Fig. 6a). Although some adult traits (in particular gill morphology) had suggested that the Natantia were not a monophyletic group, the decisive criteria for a radical systematic reorganization of the Decapoda were eventually found in reproductive traits, especially larval morphology and patterns of development (Fig. 6b).

The current system (see Bowman and Abele, 1982; Abele, 1991; Scholtz and Richter, 1995; Martin and Davis, 2001) places all taxa which release their eggs freely into the water column (namely the Sergestoidea and Penaeoidea) into the taxon Dendrobranchiata. The eggs of these "primitive" shrimps hatch as a nauplius and develop through several successive metanaupliar and protozoeal stages, before the zoeal (or mysis) phase is reached (Figs. 2a-c). Another feature of this taxon is that the juvenile and adult stages have "dendrobranchiate" gills, from which the name of this group is derived (Dall et al., 1990; Perez Farfante and Kensley, 1997; Bauer, 2004). The caridean shrimps, which formerly belonged also to the "Natantia", are now placed in the taxon Pleocyemata, together with the "Reptantia" (Fig. 6). These decapods have variable gill types (phyllobranchiate or tubular), but have the common feature that their eggs remain attached to the female pleopods, and the larvae hatch in a more advanced developmental state as zoeae (cf. Figs. 2d, 3a). It is now generally believed that both major Decapod taxa descended from a dendrobranchiate shrimp-like common ancestor with free spawning of eggs and a larval development through naupliar stages.

\section{From king to hermit, or from hermit to king?}

A further example of the contribution that larval studies have made to crustacean phylogeny concerns the recent controversial views about anomuran phylogeny. Bouvier (1897) postulated that the lithodid crabs (king crabs) arose from a paguroid hermit crab predecessor through a secondary process of "carcinization" (for recent arguments, see Cunningham et al., 1992; Scholtz and Richter, 1995; Scholtz, 2003). Based on evidence from adult morphology, McLaughlin and Lemaitre (1997) challenged this one-century old view. They argued in favour of an opposite evolutionary sequence, i.e. an ancestral position of the lithodids and a derived state for hermit crabs. In later publications (for review, see McLaughlin et al., 2004), most of their arguments for this alternative hypothesis were based on larval morphology, in particular on the development of the pleonal plates in the megalopa and in the early juvenile stages. Although this debate is not conclusive, it shows again how evidence from larval biology contributes to evolutionary hypotheses, stimulating potentially fruitful discussions about phylogenetic relationships within or between higher Crustacean taxa.

\section{Incongruous larvae}

When larval characters are used in phylogenetic analyses, this is always based on the fact that larval traits are genetically hereditable. The most extreme hypothesis proposed concerning evolutionary history of the Crustacea and other invertebrate taxa using larval evidence was by D.I. Williamson (see Williamson 1992, 1998, 2001; Williamson and Rice, 1996; and earlier papers cited therein). It accounts for "incongruous 

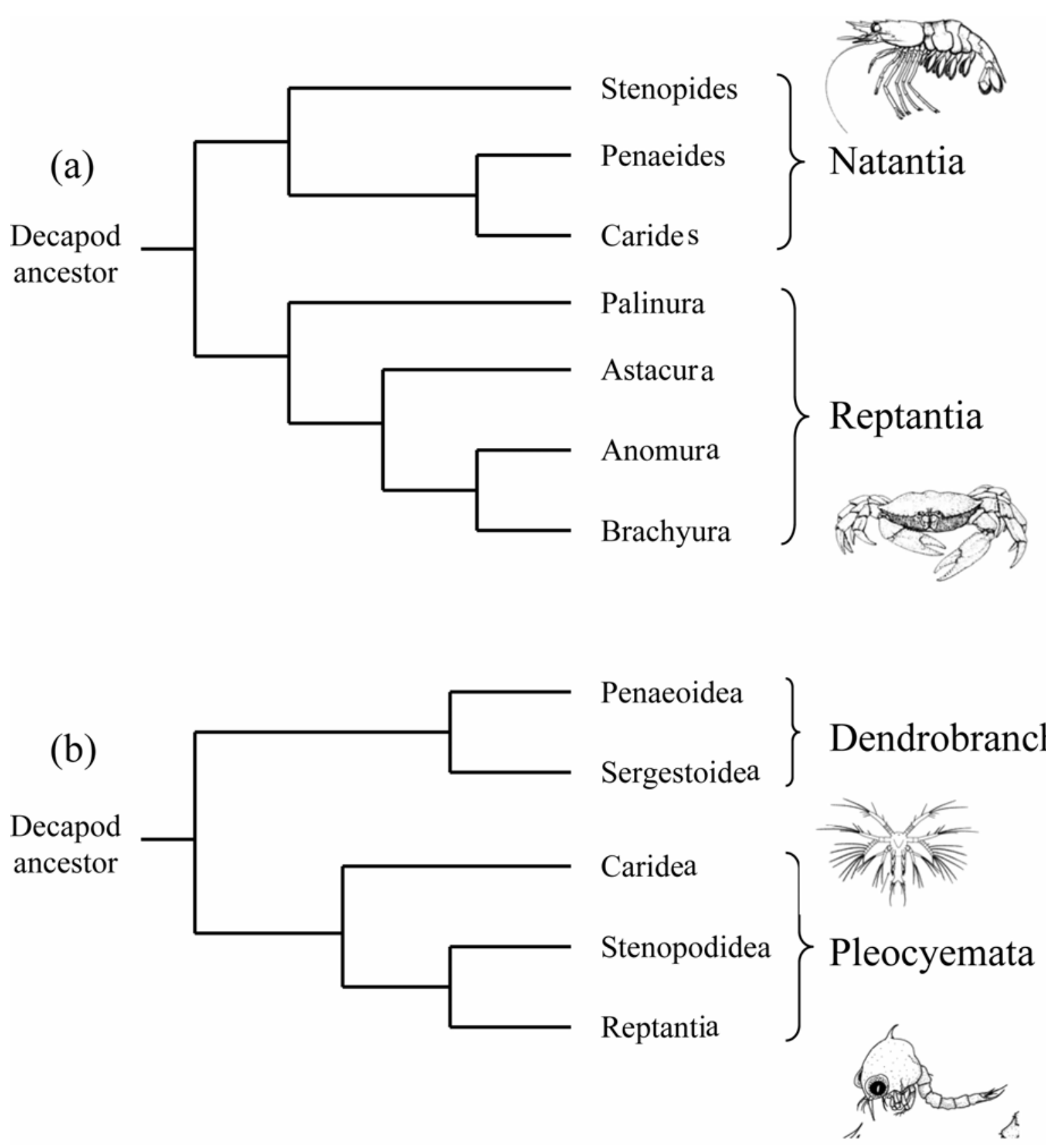

Fig. 6. Phylogeny of the Decapoda. (a) old system (after Borradaile, 1907), based on adult morphology; (b) modern system, based predominantly on reproductive and larval traits (after Bowman and Abele, 1982; Abele, 1991; for further references, see Bauer, 2004); note: the modern Reptantia comprise the taxa Thalassinidea, Astacidea, Palinura, Anomura, and Brachyura.

larvae”, which appear intermediate between systematically distant groups, for instance the zoeae of dromioid crabs, which are morphologically intermediate between those of brachyurans and anomurans. According to Williamson's hypothesis, such larvae result from occasional transfers of genes coded for larval features from one phylogenetic lineage to another. In such hybrid life-histories, larvae should thus originate from a different evolutionary line from that of the adults. On the one hand, as a conceivable mechanism, Williamson suggested that the expression of paternal genes specified the larval form, while the expression of maternal genes specified later phases of development. Among other consequences, the author proposed the removal of palinurid lobsters as a convergent group from the Eucarida (i.e., also from the Decapoda), because of their bizarre phyllosoma larvae. On the other hand, he included the mysidaceans because these peracarids possess func- 
tional uropods, as most eucarid zoeae. Although this unusual hypothesis has not been generally accepted and was criticized by taxonomists and evolutionary biologists (see Strathmann, 1993b; Scholtz, 2003), it is nevertheless testable and represents another example of a stimulating contribution of larval biology to crustacean research.

\section{Eco-Devo: Phenotypic Plasticity in Developmental Traits}

Most species-specific developmental patterns, including larval traits, are genetically fixed within a narrow range, being subject to evolutionary selection pressures (see previous section, “Evo-Devo”). However, the environment has modifying effects. This implies interactions between developmental biology and ecology, which have recently attracted increasing attention from both developmental biologists and ecologists. This represents the subject of a line of research referred to as "Ecological Developmental Biology" or briefly "EcoDevo" (Gilbert, 2001).

Survival, growth, and duration of development in the plankton are affected by current and previous variations in environmental key factors such as temperature, salinity, food concentration, light conditions, or the presence of predators (Rumrill, 1990; Morgan, 1995). Moreover, the ontogeny of physiological regulatory systems (Spicer and Burggren, 2003), larval morphology, and even the number of developmental stages passed from hatching to metamorphosis, may vary intraspecifically, depending on environmental conditions. This phenomenon, termed phenotypic plasticity, has been particularly well documented and modeled for life histories of insects and amphibians (for recent review, see Bayne and Honkoop, 2003; Piersma and Drent, 2003, Pigliucci, 2005). Among the Crustacea, its occurrence is especially common for euphausids and caridean shrimps (Rumsey and Franks, 1999; Knowlton and Vargo, 2004), to a lesser extent for anomuran and brachyuran crabs, lobsters and other decapods (for references, see Anger, 2001; Strasser and Felder, 2001; Zeng et al., 2004). It is presumably caused by environmentally altered patterns of gene-expression coding for successive steps in the ontogeny of the phenotype (Gilbert, 2001). The brown shrimp, Crangon crangon, for instance, shows morphological variability at particular larval stages (Fig. 3b), which is commonly correlated with variation in environmental factors such as food, temperature, and salinity (Criales and Anger, 1986). The estuarine crab Chasmagnathus granulata is another example. This species can either pass through a short developmental pathway with four zoeal stages or through a longer one with five stages, depending on both extrinsic and intrinsic factors. These include variations in salinity during embryonic development, egg size, initial larval biomass at hatching, salt concentrations and food availability during larval development, and variability in maternal condition or genetic factors (Giménez et al., 2004, and earlier papers cited therein).

Besides in the number of larval stages, environmentally induced intraspecific variability may occur also in other developmental traits such as age and size at metamorphosis. In larval shore crab, C. maenas, for instance, Giménez (unpubl. data) observed throughout the reproductive season (spring, early summer) a continuously decreasing trend in the size at metamorphosis, and this was positively correlated with reduced size in later juvenile instars. Similar seasonal patterns were observed in the barnacle Semibalanus balanoides, where the organic biomass (carbon content) of settling cypris larvae decreased from March through May. This trend was correlated with a seasonal decrease of early juvenile growth subsequent to settlement (Jarrett, 2003). Plasticity in the age and size at metamorphosis is commonly associated with variability in available larval food (e.g. Giménez and Anger, 2005; Howard and Hentschel, 2005). However, various other environmental factors can have modifying effects, for instance the presence or absence of chemical cues from the parental habitat (see below, section on habitat choice and control of settlement).

In crustaceans with strong developmental plasticity (e.g. in euphausids and caridean shrimps), suboptimal ecological conditions tend to increase the number of larval stages and reduce the average extent of morphological change (morphogenesis) and growth per moult (Anger, 2001). This does not necessarily imply however, that a longer developmental pathway represents simply a pathological delay of settlement and metamorphosis. For species that live in physically or nutritionally highly variable environments (e.g. in estuaries), variable developmental pathways may provide an enhanced flexibility. When temporally or locally optimal conditions occur, a short development to metamorphosis may enhance the chance for rapid recruitment in a favourable habitat, while a stress-induced delay of metamorphosis may allow for continued larval transport, enhancing the chance to find another environment that is more suitable for settlement and subsequent juvenile growth and maturation. In unpredictable environments, phenotypic plasticity in larval development may thus have an adaptive value, offering an advantage over strongly canalized modes of development. This implies that the extent of phenotypic plasticity is a species-specific trait, which is itself under selection pressure. In genetically isolated populations, distinct conditions may select for particular phenotypes, 
eventually resulting in speciation (Arthur, 2000: “all evolutionary novelties ultimately arise from intraspecific variation"). In conclusion, developmental plasticity may have implications for local recruitment, ecological and geographical patterns of distribution, ecosystem structure, and speciation. At least for crustaceans, however, there are only few comparative studies showing species-specific limits of variability, correlations with particular environmental variables, or a potential adaptive value of plasticity under various ecological scenarios (Anger, 2001; for recent discussion, Giménez, 2003; Giménez et al., 2004). The study of intraspecific variability of ontogenetic traits remains therefore a major challenge for future crustacean research.

\section{Supply-Side Ecology: Planktonic Larvae as a Bottleneck in Benthic Population Dynamics}

Knowledge of relationships between environmental factors and larval survival, both in the plankton and at settlement in the benthic-pelagic interface, is critical for one of the most influential theories of benthic marine ecology, termed “supply-side ecology” (Young, 1987; Roughgarden, 1989; for recent review, see Connolly and Roughgarden, 1999; Ross, 2001; Svensson et al., 2004). This approach, ultimately based on Thorson's classical studies (Thorson, 1950, 1961), regards larval supply as one of the key variables in benthic-pelagic coupling. This implies a crucial role - or a bottleneck function - of larval recruitment for the stability of benthic populations and communities.

\section{Wanderers between two worlds: larvae in benthic- pelagic coupling}

When benthic invertebrates release their larvae into the water column, the offspring are locally or regionally dispersed by currents, and the larvae exploit planktonic food sources, which may not be directly available to conspecific adults (McEdward, 1995, 2000; Pechenik, 1999). Most macrobenthic crustaceans are predators or scavengers, and even filter-feeding species may capture suspended particles that differ in size or quality from the food items commonly utilized by the larvae (comprising mostly microzooplankton and phytoplankton; Anger, 2001). Moreover, meroplanktonic larvae play an inverse trophic role, i.e. as a food source for pelagic predators and suspension-feeders, especially in coastal and estuarine regions. At settlement, competent larvae recruit to existing populations of the same species (although rarely to the population of origin; see Swearer et al., 2002), or they may colonize new benthic habitats, where their arrival can modify the structure of previously established communities. The role of larvae in benthicpelagic coupling is thus not limited to trophic aspects (the exchange of energy and matter), but comprises also numerous other interactions including competition for space and food, cannibalism, and commensal relationships (Conolly and Roughgarden, 1999; Pechenik, 1999; Menge, 2000; Luppi et al., 2002; Eckert, 2003).

The success of complex life-history strategies depends primarily on the survival of larvae in the plankton where predation, temporal or local limitation of food availability, unsuitable temperatures or salinities or other adverse conditions reduce the supply of settlers to the benthos (for review of larval mortality factors, see Rumrill, 1990; Morgan, 1995; Pechenik, 1999). As a consequence, a long period of planktonic larval development allows for continued growth and extended dispersal, but on the other hand, enhances also the probability of being eaten by pelagic predators, advected out of the favourable ecological range, or dying for other reasons before the time of settlement and metamorphosis is reached (Morgan, 1995; Eckert, 2003).

As a recent example of supply-side ecology, Conolly and Roughgarden (1998, 1999) and Conolly et al. (2001) showed that the interannual variation of barnacle and crab settlement near the Californian coast is associated with variations in prevailing meteorological and oceanographic conditions during the reproductive season. The prevalence of offshore winds causes upwelling conditions with an enhanced offshore advection of competent larvae and thus a reduced onshore supply and poor settlement. El Niño events, on the other hand, favour onshore transport and enhanced coastal settlement, causing profound changes in benthic community structure. Inversely, Giménez (in prep.) observed at the offshore island of Helgoland (North Sea), low settlement rates for the shore crab, Carcinus maenas, during a year with prevailing onshore currents, while a prevalence of offshore currents during the following year enhanced the settlement of megalopae presumably originating from coastal Wadden Sea populations (Fig. 7). For the barnacle species Elminius modestus, previously introduced from subtropical New Zealand waters into the North Sea, the interannual variation of recruitment success during summer (mainly July) revealed a positive correlation with previous water temperatures during winter and early spring (see below, Fig. 9). Presumably, cold winters affect the reproductive output of this warm-water species. A high correlation between barnacle densities observed at the end of the year and previous winter-spring temperatures (Fig. 9b) indicated that population structure was, in that case, primarily determined by settlement intensity (larval 


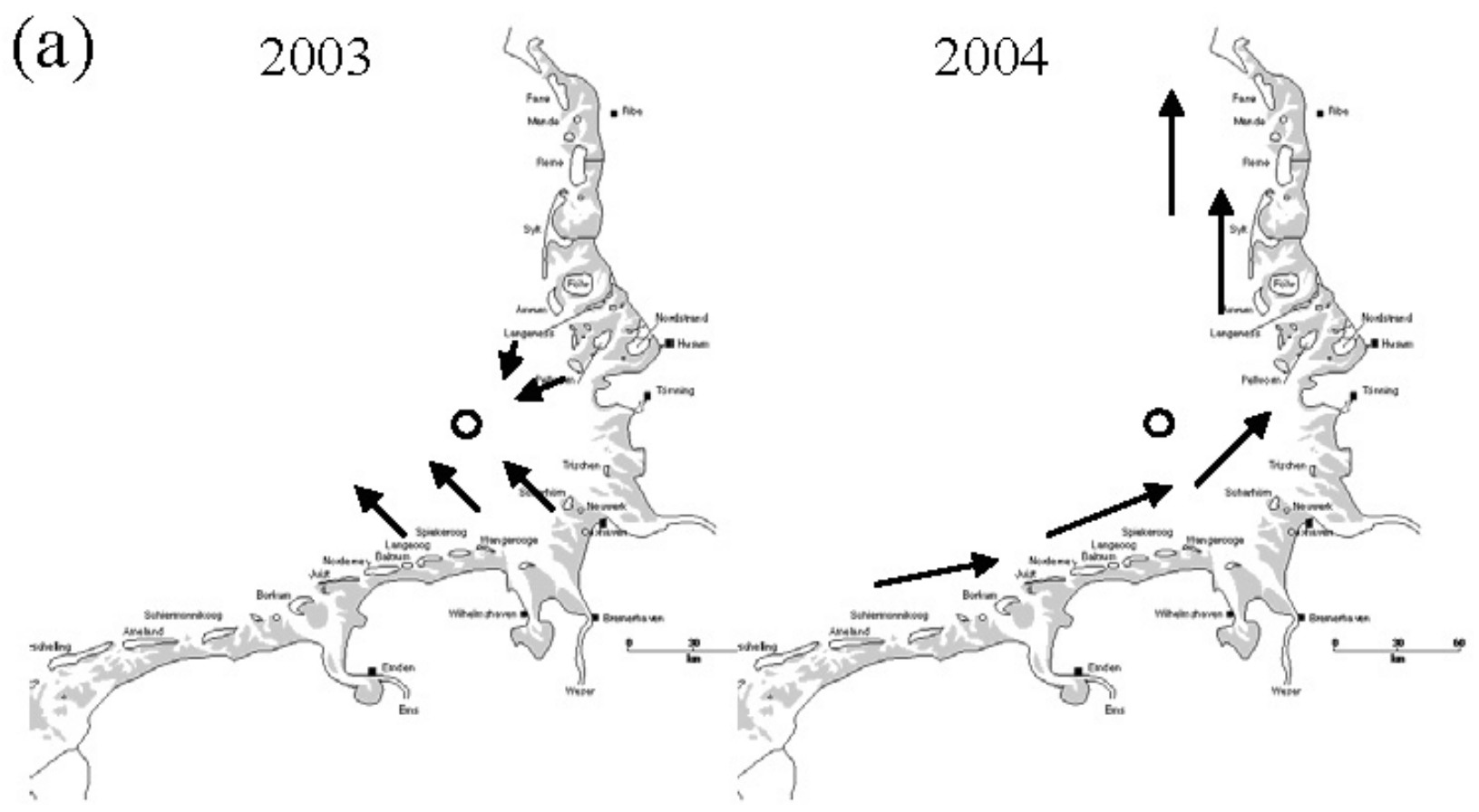

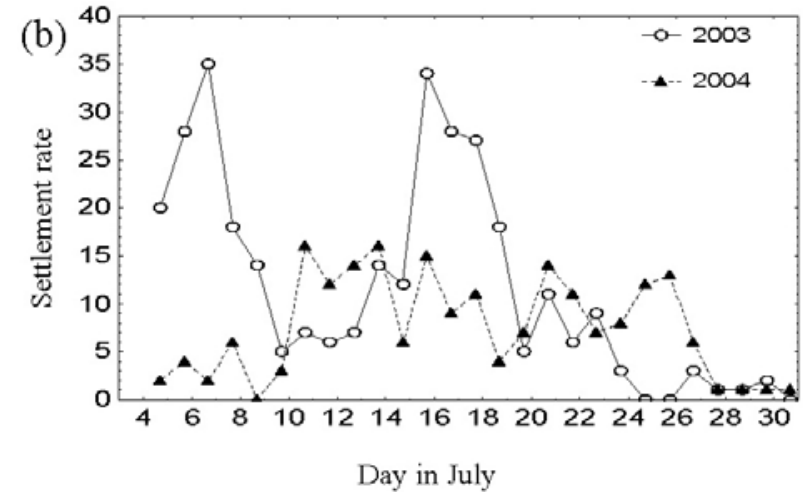

supply) and not by postsettlement survival in the benthos.

Variation in larval supply can affect benthic community structure also in a more indirect way. Barnacles, for instance, provide a hard substratum that facilitates the settlement of the larvae of conspecific or other hard-bottom dwellers (gregarious settlement, "founder effects"; Conolly and Roughgarden, 1999; Menge, 2000). Benthic predator-prey relationships also may be affected by changing patterns of larval recruitment. This was shown, for example, for the trophic interaction between the shore crab, C. maenas, and one of its most important prey species, the clam Macoma baltica. This predation is particularly strong in summer, when the early juvenile crabs eat great numbers of newly settled clam spat. It had been shown that the recruitment success of the clams tended to be higher in years with unusually low temperatures in
Fig. 7. Example for studies in supply-side ecology: tentative relationships between rates of recruitment to an isolated island population of the shore crab, Carcinus maenas, in the North Sea and larval supply from distant coastal populations. (a) Prevailing directions of currents in the German Bight during the reproductive season in 2003 and 2004, after models by Bundesamt für Seeschifffahrt und Hydrographie, BSH, Hamburg; map from GKKS web page (www.gkss.de/watis/ IMAGES/ WWF_ WM_Map.gif), modified; (b) settlement rates at Helgoland (open circle on map) during July in the same years; after Giménez (in prep.).

winter and spring. Such conditions significantly delay the period of planktonic development for both larval clams and crabs, but this delaying effect was found to be stronger in crab recruitment (Strasser and Günther, 2001). As a consequence of differential temperature effects, young crabs appeared too late in the benthos to significantly prey on early juvenile clams, because many of these had now attained a larger body size that made them unsuitable as prey items. Since these clams represent also an important food source for demersal fish species, such shifts in predator-prey interactions between benthic invertebrates may not only affect the ecological structure of benthic communities, but eventually also the production of commercially exploited fish populations (Strasser and Günther, 2001). Again, an improved understanding of such fundamental relationships requires more infor-mation from larval biology. 


\section{A decisive transition: habitat choice and control of settlement}

Larval supply is also affected by factors other than variation of reproductive output, mortality in the plankton, and transport processes. The crucial transition from a planktonic to a benthic life style is ultimately determined also through an active larval "decision" for a particular habitat, where settlement and metamorphosis are initiated.

Among the Crustacea, this highly important aspect of supply-side ecology has been studied most extensively in barnacles, because the population structure of sessile species is not influenced by confounding effects of postsettlement immigration or emigration of juvenile or adult individuals. Hence, their populations depend critically on the "right" habitat choice by settling larvae, which must successfully metamorphose at locations that confer a high probability of subsequent survival to reproduction. By comparison, for motile crustaceans such as crabs, lobsters, or shrimps the benthic postsettlement stages are able later to emigrate to more suitable habitats, so that the selection of a favourable habitat at settlement seems to be less critical (Moksnes et al., 2003; Moksnes, 2004).

Since the classical studies by D.J. Crisp and earlier workers on the larval biology of cirripedes (reviewed by Crisp, 1974; Lewis, 1978), a considerable number of investigations has been carried out both in the field and laboratory (for references, see recent papers by Ross, 2001; Jenkins and Hawkins, 2003; Cruz et al., 2005, Watson et al., 2005). These studies have contributed substantially to the understanding and modeling of hardbottom ecology, explaining and predicting in much detail how the various physical, chemical, and biotic factors control the dynamics of settlement and subsequent interactions in the benthos (see Connolly and Roughgarden, 1999; Menge, 2000; Svensson et al., 2004).

Through the perception of environmental cues, which are usually associated with a preferred type of habitat, the settlement stages of barnacles and other sessile invertebrates are generally capable of identifying suitable locations for metamorphosis (for general review, see Pechenik, 1990; Rittschof et al., 1998). If such cues are absent, the larvae can prolong their planktonic phase and delay settlement and metamorphosis. Among the various physical cues that can effectively stimulate or prevent larval settlement, are surface texture and other structural bottom characteristics, light, salinity, water currents, and vibrations. The most commonly observed chemical cues comprise odours that indicate particular types of water (e.g., humic acids from estuaries), those originating from bio- tic substrates (e.g. macroalgae, seegrasses), from predators, food organisms, hosts (in parasitic and commensal species), or conspecific adults. For hermit crabs, the absence of suitable snail shells may cause a considerable delay of metamorphosis from the megalopa to the first juvenile crab stage (Harms, 1992; Harvey, 1996; Brodie, 1999). Similar responses have recently been observed also for several species of brachyuran crabs and other motile crustaceans, suggesting a more widespread occurrence of such control mechanisms for benthic marine species with complex life histories (review by Anger, 2001; Forward et al., 2001; Gebauer et al., 2003).

The identification of physical and chemical cues from the habitat depends on a well-developed sensory and nervous system, especially on the modality of chemoreception. Recent experimental studies (Gebauer et al., 2002) have revealed that not only odours released by conspecific adults, but also those from closely related species are effective for stimulating metamorphosis (Fig. 8). The strength of the larval response tended to decrease with increasing phylogenetic distance, suggesting that the structure of chemical cues (presumably pheromones) might reflect phylogenetical relationships within a clade. Also, this implies that the response to species-specific cues may represent a heritable trait which must be subject to natural selection. Since this capability is particularly advantageous for species with specialized habitat requirements (for instance, in commensal crabs; see Castro, 1978), it may be considered as an evolutionary adaptation.

Besides attracting cues, there are also natural repellents, e.g. chemical compounds, indicating the presence of predators (kairomones). While effects and chemical properties of both pheromones and kairomones have been extensively studied in freshwater ecosystems, much less is known about their roles for marine larvae (for recent advances, see Forward and Rittschof, 2000; Cohen and Forward, 2003). The significance of chemical communication for larval survival through metamorphosis thus remains a challenge for future research which should confer further important contributions of larval biology to the biology of crustaceans and other aquatic invertebrates.

In conclusion, the understanding of larval settlement is as critically important for benthic ecology and population dynamics as is the knowledge of environmental effects on larval development and survival in the plankton. This is also crucial information for applied biology including the fisheries and aquaculture of commercially exploited species where predictions of recruitment are vital for resource management and protection. Conversely, the prevention of settlement using selective deterrents is equally important for cases 

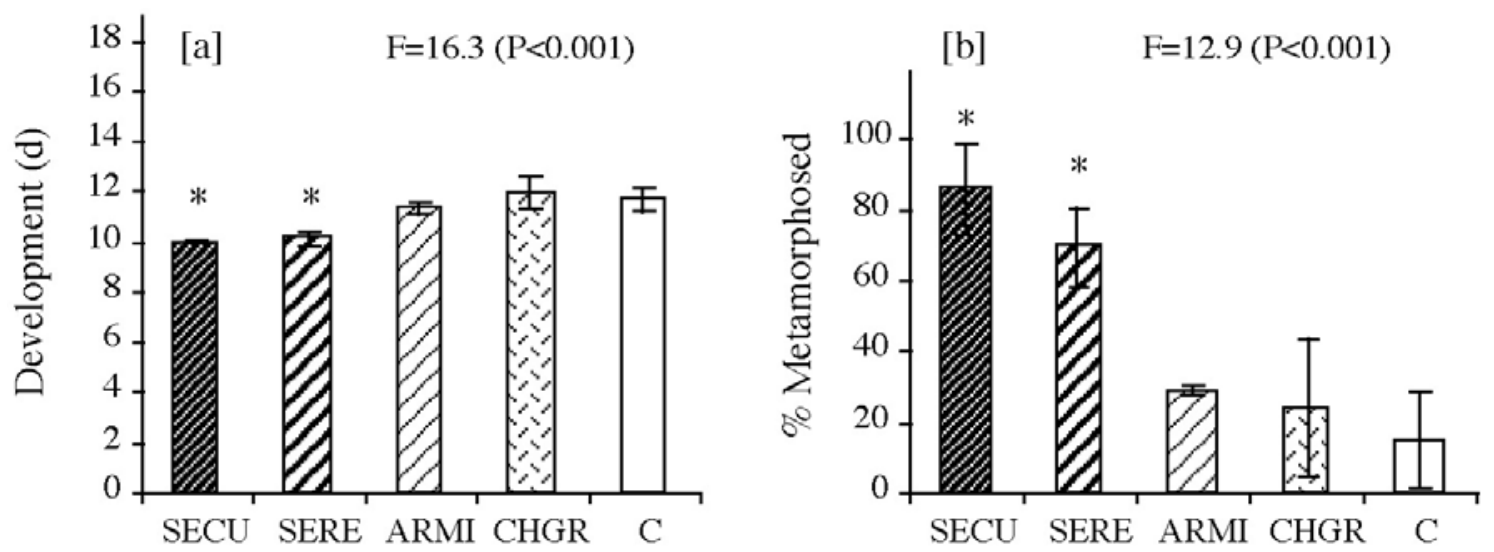

Fig. 8. Sesarma curacaoense, stimulation of metamorphosis by chemical cues: effects of adult-conditioned water with odors from conspecifics (SECU), a congener (Sesarma rectum, SERE), or other grapsoid crab species (Armases miersii, ARMI; Chasmagnathus granulata, CHGR); C: control group (filtered seawater, not conditioned with adults); (a) duration of development (days) through the megalopa stage; (b) percentage of metamorphosed megalopae (mean \pm SD) on day 10 (the day when, in the treatment with the fastest development, at least $50 \%$ of the megalopae passed through metamorphosis); F statistic; $\mathrm{P}$, probability of error for rejecting the null hypothesis; *, significant difference $(P<0.05)$, based on multiple comparisons (after Gebauer et al., 2002, modified).

where larval recruitment is considered as undesirable, especially the prevention of fouling on surfaces of ships and harbour constructions or inside cooling water intakes of power plants. Again, barnacles play a prominent role in antifouling research, and provide numerous examples of contributions of larval biology to both basic and applied crustacean research (Rittschof et al. 1998; Clare et al. 1999; Connolly and Roughgarden, 1999; Menge, 2000; Nogata et al., 2003, Nylund and Pavia, 2003).

\section{Carry-over effects: larval condition and postsettlement fitness}

It is generally acknowledged that, in addition to larval supply and selective settlement, post-settlement events in the benthos determine the success of recruitment processes (e.g., Hughes et al., 2000; Fraschetti et al., 2002; Svensson et al., 2004). The relative importance of pre- and postsettlement interactions varies among species and habitats, and with density and scale of recruitment (Menge, 2000; Delany et al., 2003). Moreover, it depends on the fitness of new settlers, which is influenced by previous larval history. This implies that "metamorphosis is not a new beginning", as Pechenik et al. (1998) put it, but only a transition between two major phases of a life history. The same concept applies to the process of hatching, because the fitness of the planktonic larvae is affected also by the conditions under which the embryos had developed. When late effects of previously experienced conditions (in physiology termed "acclimatization" or "acclimation”; Kinne, 1964, 1967) persist through successive phases of the life cycle, they are commonly referred to as "carry-over effects".

This phenomenon has been observed in various aquatic invertebrates with complex life histories, for instance for ascidians (Bennet and Marshall, 2005), bryozoans (Ng and Keough, 2003), molluscs (Phillips, 2004), barnacles (Thiyagarajan et al., 2005), and crabs (Giménez, 2004; Gebauer et al., 2003; Giménez et al., 2004). Acclimation includes changes in the adjustment of physiological mechanisms such as the temperaturedependence of metabolic processes (Pörtner, 2002) or the expression of osmoregulatory capabilities (Charmantier, 1998). Presumably those changes occur through environmentally altered gene expression patterns (Gilbert, 2001).

Shifts in larval temperature or salinity tolerance due to previous embryonic acclimation represent typical carry-over effects (e.g. Rosenberg and Costlow, 1979; Bas and Spivak, 2003). For the first-stage zoeae of the estuarine crab Chasmagnathus granulata, for instance, Charmantier et al. (2002) showed that the capacity for hyper-osmoregulation was enhanced after previous exposure of the eggs to reduced salinity. This late effect of embryonic acclimation to hypo-osmotic conditions persisted throughout the larval development to metamorphosis (Giménez and Anger, 2003). For the same species, the salinity conditions prevailing during the embryonic phase were shown to affect also the initial larval biomass at hatching, which had consequences for the subsequent pattern of development, and this influenced the body size and nutritional vulnerability of the early juvenile crabs (Giménez, 2004; Giménez et al., 
2004). This demonstrates that carry-over effects are important in the context of supply-side ecology. There are not only historical effects persisting from the embryonic to the larval phase, but also those carried over from planktonic larval experience to postsettlement stages, affecting the fitness of the early benthic juveniles. Compared to embryonic-larval interactions, however, relatively little is known about carry-over effects throughout metamorphosis. Again, in this respect barnacles have been studied in more detail than decapods and other crustaceans (e.g. Jarret, 2003; Thiyagarajan et al., 2005).

\section{Larval Dispersal: Implications for Biogeography, Invasiveness, and Speciation}

\section{Scales of dispersal}

For aquatic invertebrates with complex life cycles, the strategy of dispersal is closely related to the mode of development (Grantham et al., 2003). Dispersal determines local ecological distributions (see above, supplyside ecology), regional distribution patterns of populations and metapopulations, as well as the geographic range of species (Bowler and Benton, 2005). For the most extreme cases, a very short duration of the larval phase (minutes to hours) may allow only a small-scale dispersal and settlement within or near to the population of origin (scale: about $100 \mathrm{~m}$ ), whereas an extended mode of planktonic development (several months) favours a large-scale transport over hundreds or thousands of kilometers (Day and McEdward, 1984). In species with very long-lasting planktonic phases, larvae may even cross oceanic barriers between continents ("teleplanic" or "long-distance" larvae; Scheltema, 1986). As a consequence, such species generally show a wide range of geographic distribution, although this may be limited by mechanisms favouring a regional larval retention or a return of late-stage larvae to the region of origin (see Bradford et al., 2005; Chiswell and Booth, 2005; Jeffs et al., 2005). Oceanic dispersal probably played an important role in the palaeobiogeography and evolution of both aquatic and terrestrial organisms (Scheltema, 1986; de Queiroz, 2005). The mode of larval development and dispersal also has implications for the temporal range of individual lineages, as a high degree of connectivity among populations tends to reduce the extinction rate over geological time scales (cf. Fig. 1b).

Among the Crustacea, both extremely short or extended modes of planktonic development are relatively uncommon. Larval long-distance transport has been documented for palinurid lobsters, for which the phyllosoma phase may last for up to two years (Bradford et al., 2005; George, 2005). The overwhelming majority of the Crustacea passes through a larval period of intermediate duration from a few weeks to months (Thorson, 1946, 1950). Field observations and mathematical models suggest that such periods allow for transports over distances ranging between a few tens and a few hundreds of kilometres, i.e. mostly on a regional scale (for review, see Day and McEdward, 1984; recent papers by Pedersen et al., 2003; Queiroga and Blanton, 2005; Tilburg et al, 2005; Criales et al., 2006). In conclusion, limited larval dispersal allows regular recruitment and genetic exchange, ensuring the stability (Eckert, 2003) and the connectivity of regional benthic populations (Strathmann et al., 2002), but rarely for long-distance transport. In addition to the planktonic larval stages, however, dispersal may be enhanced through extended postsettlement migrations of early juveniles, especially in portunid swimming crabs (Etherington and Eggleston, 2003). In some species of spiny lobsters, the adults are known to make benthic migrations over hundreds of kilometres (e.g. Groeneveld and Branch, 2002; Alerstam, 2003).

Although the scale of dispersal is greatly influenced by the species-specific duration of the pelagic phase, which is modified by temperature and other environmental factors, it is important to remember that dispersal is by no means only a passive drifting process depending on time and regional currents (Bowler and Benton, 2005; Queiroga and Blanton, 2005). Larval transport depends also on a wide array of behavioural adaptations. These comprise rhythms of larval hatching (Saigusa et al., 2003; Tankersley et al., 2002a), vertical migrations in the water column (Queiroga and Blanton, 2005), and an active control of settlement and metamorphosis (e.g. Forward et al., 2001; Tankersley et al., 2002b; Gebauer et al., 2003; Shanks et al., 2003), all responding to variations in environmental key factors such as tidal currents, temperature, salinity, food concentration, hydrostatic pressure, light conditions, etc. (Forward et al., 2001; Kingsford et al., 2002; Gardner et al., 2004).

When competent larvae reach distant habitats suitable for settlement, survival and reproduction, isolated metapopulations may become established that form disjunct patterns of distribution (e.g., Botsford et al., 1994; Bilton et al., 2002, Giménez, 2003), i.e. to disjunct patterns of geographic distribution (de Queiroz, 2005). When genetic divergence occurs on larger scales of space or time (over climatic gradients or through many generations), this will eventually favour allopatric speciation, with adaptations to different or changing environments (Palumbi, 1994). On all these scales, from local population ecology to global biogeography, information from larval biology is thus essential for the 
understanding of the biology of crustaceans and other animals with complex life histories. In future research, the most promising tool for the study of relationships among modes or scales of dispersal, population structure, biogeography, and genetic divergence may be a combined approach of experimental investigations (e.g. Luppi et al., 2003), field studies (e.g. ManzanillaDominguez and Gasca, 2004), and molecular genetics (e.g. Bilodeau et al., 2005).

\section{Alien species: larval biology and invasiveness}

The invasion of native communities by alien species has recently become a the major concern for ecology and environmental protection of terrestrial, limnic and marine ecosystems (Mooney and Hobbs, 2000; Mack et al., 2000; Ruiz et al., 2000; Garcia-Berthou et al., 2005). The competitive success of non-native species in a new habitat is commonly based on preadaptations evolved in the original environment, and/or on great life-history variability (Bohn et al., 2004). In species with a limited dispersal capacity, for instance freshwater crayfish (which develop directly and not through a planktonic larval phase), the success as an invader depends greatly on superiority of agonistic or other behavioural traits, opportunistic feeding strategies, high reproductive output, short generation time, tolerance of pollutants or other stress factors, or other preadaptations of the benthic juvenile and adult life-history stages (e.g. Gherardi and Daniels, 2004; Paglianti and Gherardi, 2004; Roth and Kitchell, 2005). Additionally, spatial heterogeneity and disturbance within the benthic habitat appear to facilitate invasions (Clark and Johnston, 2005; Hastings et al., 2005).

In coastal marine environments, the initial introduction occurs in most cases probably through the transport and later disposal of ballast water from ships (Hamer et al., 1998). For invading species with complex life cycles, the larval phase is crucial not only for the establishment and persistence of new populations, but also for range extensions within recipient regions. This has been suggested, for example, for the spread of the Chinese mitten crab, Eriocheir sinensis, in Europe (Clark et al., 1998b; Herborg et al., 2003) and along the west coast of the USA (Rudnick et al., 2005). Invasions by the European shore crab, Carcinus maenas, in Australia (Thresher et al., 2003) and on both the Atlantic and Pacific coasts of North America are based on similar mechanisms (Carlton and Cohen, 2003; Behrens Yamada et al., 2005; Cameron and Metaxas, 2005). Likewise, an invasive Asian shore crab, Hemigrapsus sanguineus, is successfully spreading along the northwestern Atlantic coasts, due to both benthic preadaptations (Lohrer et al., 2000) and a high larval dispersal capacity in the plankton (Park et al., 2005). Among the non-decapod crustaceans, the invasive barnacle Elminius modestus provides another example of rapid spread into new environments, due at least, in part, to high larval dispersal capacity (Harms, 1998; Lawson et al., 2004).

All these examples demonstrate that the success of larval development and recruitment appears to be correlated with warm water temperatures. C. maenas, for instance, had unusually high rates of northward spread along the west coast of the USA that coincided with an El Niño event in 1998 (Behrens Yamada et al., 2005). Conversely, a temporary decline of conspecific populations on the American east coast around 1960 was attributed to low temperatures (Audet et al., 2003). Similarly, interannual variation of recruitment success of the introduced warm-water barnacle E. modestus correlated significantly with water temperatures in winter and spring (Fig. 9). Patterns of larval supply and recruitment of $C$. maenas in Nova Scotia, Canada, were studied also in relation to larval salinity tolerance (Cameron and Metaxas, 2005; cf. Nagaraj, 1993; Anger et al., 1998). A population inhabiting the brackish Bras d'Or Lakes revealed successful larval development and recruitment at low salinities in combination with low temperatures (a particularly challenging condition; see Charmantier, 1998; Anger, 2003), suggesting that this population might have resulted from an invasion of crabs originating from the Baltic Sea (Cameron and Metaxas, 2005). This might also explain the successful northward spread of this invader beyond the central coast of Maine, its previously predicted northern limit of reproduction (Berill, 1982). These examples show that experimental laboratory studies of larval ecophysiology, especially in combination with field studies of larval occurrence in the plankton, provide important information that allows for predictions of range expansion within or among regions.

In contrast to these extensively studied cases, the invasiveness of many other potential invaders remains largely uncertain, because not enough is known about the duration and environmental requirements of their larval stages. There is, for instance, growing concern about possible invasions in the Antarctic region, which has been considered as especially isolated and physically protected against alien invasions (Clarke et al., 2005; Frenot et al., 2005; Thatje, 2005). Lithodids, or "king crabs", are likely candidates for becoming future invaders of cold waters, especially due to larval predaptations to both low temperatures and planktonic food limitation at high latitudes (for recent review, see Anger et al., 2004; Thatje et al., 2005). In the northern hemisphere, the red king crab, Paralithodes camtschaticus, is invading Arctic coastal waters of northern 


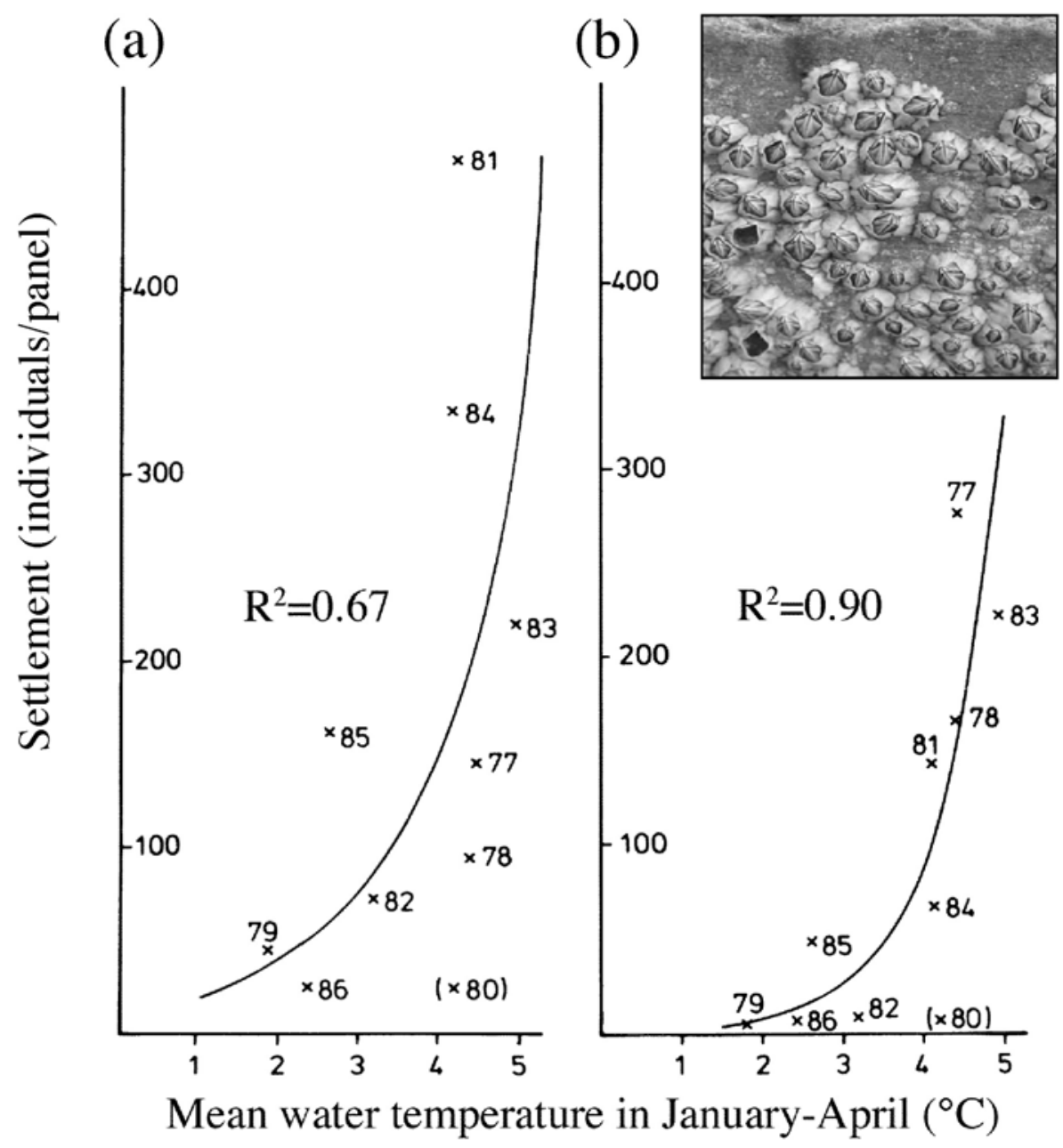

Fig. 9. Log-linear relationship between average seawater temperatures in winter and early spring, and settlement of an introduced warm-water barnacle species, Elminius modestus, on artificial near-surface test panels suspended in ten subsequent summers (1977-1986) at Helgoland, North Sea; (a), panels exposed for one month only (settlement intensity); (b), density of survivors at the end of the year (settlement success; modified, after Harms and Anger, 1989).

Russia and Norway, after intentional introduction from the Pacific. However, predictions of future rates or southern limits of spread require more information from larval biology, especially on larval temperature tolerance and nutritional requirements, but also on benthic postsettlement ecology of the early juvenile stages (Zaklan, 2002; Epelbaum and Kovatcheva, 2005; Stevens and Swiney, 2005). Benthic interactions, especially those with native predators, are important for the persistence of invasive populations (deRivera et al., 2005).

Biological invasions, in general, occur over various time scales. Introduced or "alien” species can spread in a new recipient region within a few years or decades (e.g., the Chinese mitten crab, the European shore crab), whereas those promoted by climatic change (e.g. presumable invasions by lithodids in Antarctica) may take decades or centuries. All such historical invasions are short-term events compared to evolutionary invasions, which take numerous generations and geological periods of time. Examples will be shown in the following section.

\section{Limnic and terrestrial invasions}

Invasions of limnic and terrestrial environments by marine organisms belong to the top issues in evolutionary biology (e.g. Labandeira and Beall 1990; Little 1990; Lee and Bell 1999). Such radical changes in life style are associated with major physiological, behavioural and life-history adaptations to profoundly different environmental conditions (Greenaway 1999; Feder et al. 2000). Most so-called limnic and terrestrial species, however, are actually fully adapted to nonmarine conditions only in their juvenile and adult lifehistory stages. Their larval phase is either completely 

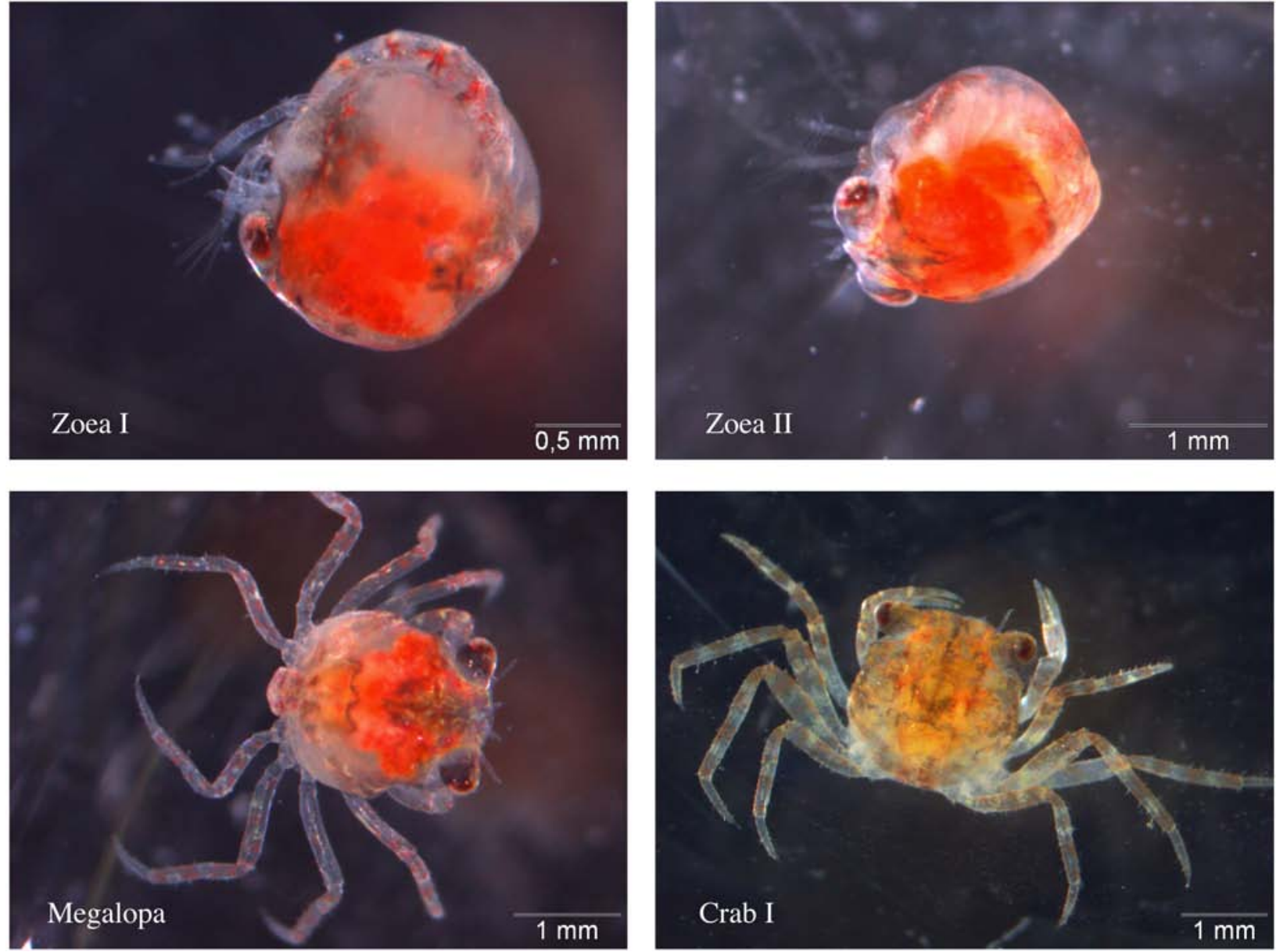

Fig. 10. Sesarma fossarum, larval stages (swimming, non-feeding zoeal stages I, II; crawling, facultatively lecithotrophic megalopa), first juvenile crab stage; photos: Anger (unpubl.).

supressed (e.g. all crayfish and potamid freshwater crabs), or the larvae are forced to evade the habitat of the conspecific adults, developing in adjacent coastal or estuarine waters (“export strategy”; Strathmann, 1982; e.g. numerous species of grapsid, ocypodid, and gecarcinid crabs, coenobitid hermit crabs, palaemonid shrimps). Only few crustacean taxa living under fully limnic or terrestrial conditions have retained a freeliving larval phase (Anger, 2001).

Signs of an incipient limnic speciation have been observed in palaemonid shrimps from Japan, Macrobrachium nipponense and Palaemon paucidens, which can live and develop in various freshwater and brackish water habitats. Compared to estuarine populations, genetically isolated freshwater populations show not only significant shifts in the salinity optimum, but also tendencies towards enhanced egg sizes (i.e., increasing energy reserves at hatching, allowing for reduced dependence on planktonic food), prolonged embryonic incubation periods, and an abbreviation of the planktonic larval phase (Mashiko and Numachi, 2000, and previous papers cited therein). Presumably, these reproductive and developmental traits are adaptations to an unpredictable planktonic food production in rivers and streams. Extremely large egg size, strongly abbreviated modes of larval development, and complete lecithotrophy have evolved repeatedly and independently in palaemonid shrimps living in freshwater habitats, mostly in South and Central America, Asia, and Australia (for recent review, see Bauer, 2004; Murphy and Austin, 2005).

Another conspicuous example of limnic and terrestrial invasions is found on the island of Jamaica. Geographic isolation and a great variety of ecological niches found on the island have permitted adaptive radiations in several animal and plant taxa (see Hedges, 1996; Schubart et al., 1998; Graham, 2003). Among the decapod crustaceans, several limnic and terrestrial sesarmid crab species have evolved during the past $4 \mathrm{Myr}$, all originating from the same ancestor (for references, see Schubart et al., 1998; Schubart and Koller, 2005). Morphological, developmental, and molecular genetic 
data indicate consistently that a euryhaline coastal species of Sesarma, which must have been a close relative of the extant $S$. curacaoense, gave rise to this non-marine radiation. Most probably, this ancestor showed preadaptations including an enhanced egg size, an abbreviated mode of larval development with only two zoeal stages and a megalopa, larval euryhalinity, and a reduced dependence on planktonic food sources (for references, see Anger, 2001, 2005).

Recent studies (Anger, 2005; Anger and Schubart, 2005) have shown that all endemic Jamaican sesarmids, for which reproductive and developmental data have become available, show consistently a short larval period comprising two swimming zoeal stages and a sluggishly crawling, benthic megalopa (Fig. 10). Larval development from hatching to metamorphosis is possible during complete absence of food. Interestingly, however, only the two zoeal stages are non-feeding (fully lecithotrophic), while the megalopa is a feeding stage. The latter is thus capable of exploiting available benthic food sources such as detritus and attached microflora or -fauna. Nevertheless, it can also successfully continue its development through metamorphosis when such food items are continuously poor or lacking (facultative lecithotrophy; for experimental evidence, see Fig. 11).

It appears that an unpredictable or on average poor production of particulate food in land-locked limnic habitats has selected for this highly flexible nutritional strategy. As far as this is known, the larval development of the endemic Jamaican sesarmids takes place in small stagnant freshwater habitats such as ephemeral pools occurring near the margins of creeks, ditches, and mountain streams, or inside burrows dug in the sediments of river banks (Anger, 2005; Anger and Schubart, 2005). The larvae of terrestrial species, such as the bromeliad crab Metopaulias depressus or the snail-shell crab Sesarma jarvisi, develop in small rainwater reservoirs that occur in leaf axils of bromeliad plants, in empty shells of terrestrial snails, or in ephemeral limestone pools (for discussion and references, see Schubart et al. 1998). The larval stages of all species belonging to this clade must be capable of hyperosmoregulation in dilute media (Charmantier, 1998; Schubart and Diesel, 1999), and their development must be largely independent of external food sources, relying on enhanced energy reserves invested by females in the production of large, yolk-rich eggs (Anger, 2005; Anger and Schubart, 2005). Since such unusual life-histories imply a low fecundity and a greatly reduced dispersal capacity, reduced genetic exchange between locally separated populations may have enhanced the rate of genetic divergence, and hence, the rate of speciation within this clade. In conclusion, information from larval

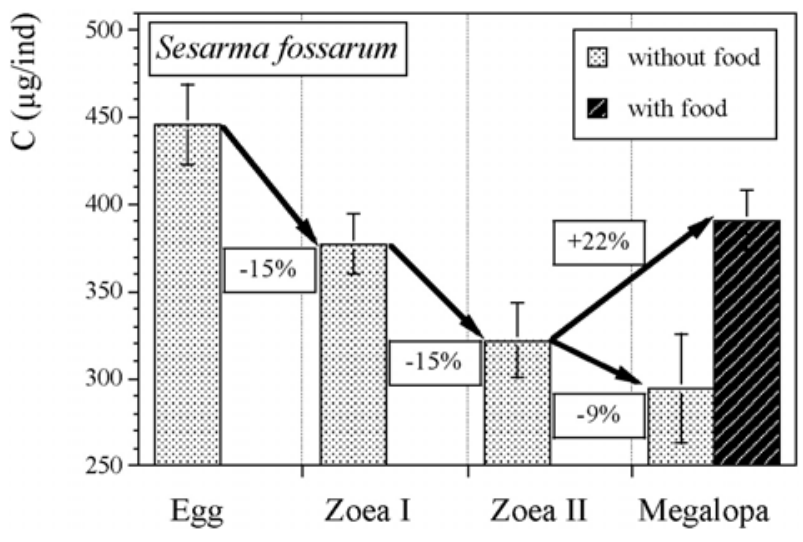

Fig. 11. Sesarma fossarum. Changes in biomass during foodindependent larval development from hatching to metamorphosis (carbon content, C, measured at the end of each stage; given in $\mu$ g per individual and as percentage values); megalopa reared with and without food (Artemia sp. nauplii). The experimental data provide evidence that the megalopa is a facultatively feeding stage, while zoeal development is fully lecithotrophic (after Anger, 2005).

biology has significantly contributed to the understanding of a spectacular case of rapid adaptive radiation of crustaceans in non-marine (brackish, freshwater and terrestrial) habitats, and thus, also to the evolutionary biology of the Crustacea. A similar although much lesser known case of adaptive radiation in sesarmid crabs appears to have occurred in Southeast Asia (Malaysia, Singapore), probably based upon similar patterns of abbreviated and food-independent larval development (see Lam, 1969). Future studies of reproductive and larval biology will, also in this case, greatly enhance the understanding of basic evolutionary mechanisms that have produced hotspots of diversity in crustaceans and other important taxa.

\section{Concluding Remarks}

Larval biology is principally the study of complex life cycles, which are wide-spread among benthic marine and other aquatic crustaceans. Since the release of larvae into the plankton, as well as larval settlement in the benthos, are prime examples of benthic-pelagic coupling, larval biology has far-reaching implications for aquatic ecology. Studies of larval biology, however, are constrained by numerous technical problems, which are associated with small larval body size, or due to difficulties in obtaining homogeneous samples of fieldcollected larvae with known taxonomic identity and a precisely identified stage of development. As a consequence, larval biology relies in some fields of research, particularly in physiology and biochemistry, 
on extrapolations from studies of larger and easier available juveniles and adults. In spite of such inherent constraints, studies of larval biology have greatly contributed to crustacean research as a whole, especially on life-history studies (ontogeny of species-specific traits) and in the reconstruction of phylogenetic relationships among higher taxa ("Evo-Devo" perspective). The nauplius larva has proved particularly important for such considerations, but phylogenetic implications have been documented also for the comparative morphology of other larval forms such as the zoea and the megalopa. It must be cautioned, however, that developmental traits may vary also in response to variation in environmental conditions (phenotypic plasticity, "Eco-Devo" perspective). In aquatic ecology, larval supply is considered one of the major determinants of benthic population structure, stability, and distribution patterns ("Supply-side Ecology" perspective). Besides the number of competent settlers (or potential recruits), also variation in larval quality may affect benthic juvenile density and fitness ("carry-over effects"). Another feature of benthic-pelagic coupling is that larvae may be incited to settle by metamorphosis-stimulating chemical cues released from the benthic habitat (e.g., odors from characteristic vegetation or from conspecific adults), or settlement may be prevented by natural repellents (e.g. kairomones indicating the presence of predators). The duration of larval development in the plankton, along with ecophysiological characteristics (e.g. larval tolerance of variations in temperature, salinity or food availability) determine the dispersal capacity of a species not only on ecological but also on biogeographic scales. Hence, information from larval biology is critical for the evaluation of distribution patterns across climatic gradients or of the invasiveness of introduced species. Finally, the study of evolutionary adaptations to nonmarine conditions (e.g., reproduction in habitats with limited availability of water; larval tolerance of low or unpredictable salinities; larval independence of planktonic food production) can significantly contribute to the understanding of speciation in limnic and terrestrial environments.

\section{Acknowledgements}

This review is based on a plenary lecture held during the Sixth International Crustacean Congress and the Fourth Crustacean Larval Conference, Glasgow, Scotland, in 2005. I cordially thank the organizers, namely Douglas M. Neil and Paul Clark, for their kind and honouring invitation to this congress. I am indebted also to numerous collaborators and students who have, during joint projects and in fruitful discussions, contributed to this paper. I am particularly grateful to Benny
Chan (Hong Kong, China), Luis Giménez (Helgoland, Germany), Jens Høeg (Copenhagen, Denmark), and Dieter Waloßek (Ulm, Germany) for kindly providing me with illustrations and additional information. Special thanks are due to Patsy McLaughlin (Shannon Point, USA), Ray Ingle (London, UK), and Peter K.L. Ng (Singapore) for improving the English of this paper and for providing numerous other suggestions and comments that helped to improve this paper.

\section{References}

Abele, L.G., Comparison of morphological and molecular phylogeny of the Decapoda. Mem. Qd Mus., 31 (1991) 101-108.

Alerstam, T., The lobster navigators. Nature, 421 (2003) 27-28.

Anger, K., The Biology of Decapod Crustacean Larvae. Crustacean Issues 14. A.A. Balkema, Lisse, The Netherlands, 2001.

Anger, K., Salinity as a key parameter in the larval biology of decapod crustaceans. Invert. Reprod. Develop., 43 (2003) 29-45.

Anger, K., The early life history of Sesarma fossarum, an endemic freshwater crab from Jamaica. Invert. Reprod. Develop., 47 (2005) 63-72.

Anger, K. and Schubart, C.D., Experimental evidence of food-independent larval development in endemic Jamaican freshwater-breeding crabs. Physiol. Biochem. Zool., 78 (2005) 246-258.

Anger, K., Lovrich, G.A., Thatje, S. and Calcagno, J.A., Larval and early juvenile development of Lithodes santolla (Molina, 1782) (Decapoda: Anomura: Lithodidae) reared at different temperatures in the laboratory. J. Exp. Mar. Biol. Ecol., 306 (2004) 217-230.

Anger, K., Montu, M., Bakker, C. and Loureiro Fernandes, L.L., Larval development of Uca thayeri Rathbun, 1900 (Decapoda: Ocypodidae) reared in the laboratory. Meeresforsch., 32 (1990) 276-294.

Anger, K., Spivak, E. and Luppi, T., Effects of reduced salinities on development and bioenergetics of early larval shore crab, Carcinus maenas. J. exp. mar. Biol. Ecol., 220 (1998) 287-304.

Arthur, W., Intraspecific variation in developmental characters: the origin of evolutionary novelties. Amer. Zool., 40 (2000) 811-818.

Audet, D., Davis, D.S., Miron, G., Moriyasu, M., Benhalima, K. and Campbell, R., Geographical expansion of a nonindigenous crab, Carcinus maenas (L.), along the Nova Scotian shore into the southeastern Gulf of St. Lawrence, Canada. J. Shellfish Res., 22 (2003) 255-262.

Bas, C.C. and Spivak, E.D., Effects of embryonic salinity exposure on larval development in two populations of the estuarine crab Chasmagnathus granulatus Dana, 1851 (Crustacea: Brachyura). Invert. Reprod. Develop., 43 (2003) 117-123.

Bauer, R.T., Remarkable Shrimps: Adaptations and Natural History of the Carideans. University of Oklahoma Press, Norman, 2004. 
Bayne, B. and Honkoop, P.J.C., Phenotypic flexibility and the evolution of organismal design. Trends Ecol. Evol., 18 (2003) 554-555.

Behrens Yamada, S., Dumbauld, B.R., Kalin, A., Hunt, C.E., Figlar-Barnes, R. and Randall, A., Growth and persistence of a recent invader Carcinus maenas in estuaries of the northeastern Pacific. Biol. Invasions, 7 (2005) 309321.

Beltz, B.S., Helluy, S.M., Ruchhoeft, M.L. and Gammill, L.S., Aspects of the embryology and neural development of the American lobster. J. Exp. Zool., 261 (1992) 288297.

Bennett, C.E. and Marshall, D.J., The relative energetic costs of the larval period, larval swimming and metamorphosis for the ascidian Diplosoma listerianum. Mar. freshw. Behav. Physiol., 38 (2005) 21-29.

Berrill, M., The life cycle of the green crab Carcinus maenas at the northern end of its range. J. Crust. Biol., 2 (1982) 31-39.

Bilodeau, A.L., Felder, D.L. and Neigel, J.E., Population structure at two geographic scales in the burrowing crustacean Callichirus islagrande (Decapoda, Thalassinidea): historical and contemporary barriers to planktonic dispersal. Evolution, 59 (2005) 2125-2138.

Bilton, D.T., Paula, J. and Bishop, J.D.D., Dispersal, genetic differentiation and speciation in estuarine organisms. Est. Coast. Shelf Sci., 55 (2002) 937-952.

Bohn, T., Sandlund, O.T., Amundsen, P.A. and Primicerio, R., Rapidly changing life history during invasion. Oikos, 106 (2004) 138-150.

Borradaile, L.A., On the classification of the decapod crustaceans. Ann. Mag. nat. Hist., Ser. 7, 19 (1907) 457-486.

Botsford, L.W., Moloney, C.L., Hastings, A., Largier, J.L., Powell, T.M., Higgins, K. and Quinn, J.F., The influence of spatially and temporally varying oceanographic conditions on meroplanktonic metapopulations. Deep-Sea Res. Part II, 41 (1994) 107-145.

Bouvier, E.L., La transformation des Bernards l'Ermite en Lithodes. Naturaliste, 2(19) (1897) 41-43.

Bosc, L.A.G., Histoire naturelle des Crustacés, contenant leur Descritption et leurs Mœurs; avec figures dessinées d'après nature. Paris, Chez Deterville. 2, 1802.

Bowler, D.E. and Benton, T.G., Causes and consequences of animal dispersal strategies: relating individual behaviour to spatial dynamics. Biol. Rev., 80 (2005) 205-225.

Bowman, T.E. and Abele, L.G., Classification of the recent Crustacea. In: Systematics, the Fossil Record and Biogeography, The Biology of Crustacea, Vol. 1, Abele, L.G. (ed.), Academic Press, New York, 1982, pp. 1-27.

Bradford, R.W., Bruce, B.D., Chiswell, S.M., Booth, J.D., Jeffs, A. and Wotherspoon, S., Vertical distribution and diurnal migration patterns of Jasus edwardsii phyllosomas off the east coast of the North Island, New Zealand. N.Z. J. mar. freshw. Res., 39 (2005) 593-604.

Brodie, R.J., Ontogeny of shell-related behaviors and transition to land in the terrestrial hermit crab Coenobita compressus H. Milne Edwards. J. exp. mar. Biol. Ecol., 241 (1999) 67-80.

Cameron, B. and Metaxas, A., Invasive green crab, Carcinus maenas, on the Atlantic coast and in the Bras d'Or Lakes of Nova Scotia, Canada: larval supply and recruitment. J. mar. biol. Ass. U.K., 85 (2005) 847-855.

Carlton, J.T. and Cohen, A.N., Episodic global dispersal in shallow water marine organisms: the case history of the European shore crabs Carcinus maenas and C. aestuarii. J. Biogeogr., 30 (2003) 1809-1820.

Castro, P., Settlement and habitat selection in the larvae of Echinoecus pentagonus (A. Milne Edwards), a brachyuran crab symbiotic with sea urchins. J. exp. mar. Biol. Ecol., 34 (1978) 259-270.

Chan, B.K.K., Poon, D.Y.N. and Walker, G., Distribution, adult morphology, and larval development of Sacculina sinensis (Cirripedia: Rhizocephala: Kentrogonida) in Hong Kong coastal waters. J. Crust. Biol., 25 (2005) $1-10$.

Chang, E.S. and Bruce, M.J., Ecdysteroid titers of larval lobsters. Comp. Biochem. Physiol., 70 (1981) 239-241.

Chang, E.S., Chang, S.A. and Mulder, E.P., Hormones in the lives of crustaceans: an overview. Am. Zool., 41 (2001) 1090-1097.

Charmantier-Daures, M. and Vernet, G., Moulting, autotomy, and regeneration. In: The Crustacea, Traité De Zoologie, Vol. 7, Forest, J. and Vaupel Klein, J.C. Brill (eds.), Leiden, 2004, pp. 161-255.

Charmantier, G., Ontogeny of osmoregulation in crustaceans: a review. Invert. Reprod. Develop., 33 (1998) 177-190.

Charmantier, G., Giménez, L., Charmantier-Daures, M. and Anger, K., Ontogeny of osmoregulation, physiological plasticity, and larval export strategy in the grapsid crab Chasmagnathus granulata (Crustacea, Decapoda). Mar. Ecol. Prog. Ser., 229 (2002) 185-194.

Chiswell, S.M. and Booth, J.D., Distribution of mid- and late-stage Jasus edwardsii phyllosomas: implications for larval recruitment processes. N.Z. J. mar. Freshw. Res., 39 (2005) 1157-1170.

Christiansen, M.E. and Costlow, J.D., Ultrastructural study of the exoskeleton of the estuarine crab Rhithropanopeus harrisii: effect of the insect growth regulator Dimilin ${ }^{\circledR}$ (Diflubenzuron) on the formation of the larval cuticle. Mar. Biol., 66 (1982) 217-226.

Clare, A.S., Rittschof, D., Gerhart, D.J., Hooper, I.R. and Bonaventura, J., Antisettlement and narcotic action of analogues of diterpene marine natural product antifoulants from octocorals. Mar. Biotechnol., 1 (1999) 427-436.

Clark, G.F. and Johnston, E.L., Manipulating larval supply in the field: a controlled study of marine invasibility. Mar. Ecol. Prog. Ser., 298 (2005) 9-19.

Clark, P.F., Interpreting patterns in chaetotaxy and segmentation associated with abbreviated brachyuran zoeal development. Invert. Reprod. Develop., 38 (2000) 171181.

Clark, P.F., The evolutionary significance of heterochrony in the abbreviated zoeal development of pilumnine crabs (Crustacea: Brachyura: Xanthoidea). Zool. J. Linn. Soc., 143 (2005) 417-446.

Clark, P.F., Calazans, D.K. and Pohle, G.W., Accuracy and standardization of Brachyuran larval descriptions. Invert. Reprod. Develop., 33 (1998a) 127-144. 
Clark, P.F., Rainbow, P.S., Robbins, R.S., Smith, B., Yeomans, W.E., Thomas, M. and Dobson, G., The alien Chinese mitten crab, Eriocheir sinensis (Crustacea: Decapoda: Brachyura), in the Thames catchment. J. mar. biol. Ass. U.K., 78 (1998b) 1215-1221.

Clarke, A., Barnes, D.K.A. and Hodgson, D.A., How isolated is Antarctica? Trends Ecol. Evol., 20 (2005) 1-3.

Cohen, J.H. and Forward, R.B., Ctenophore kairomones and modified aminosugar disaccharides alter the shadow response in a larval crab. J. Plankton Res., 25 (2003) 203-213.

Connolly, S.R. and Roughgarden, J., A latitudinal gradient in northeast Pacific intertidal community structure: evidence for an oceanographically based synthesis of marine community theory. Am. Natur., 151 (1998) 311-326.

Connolly, S.R. and Roughgarden, J., Theory of marine communities: competition, predation, and recruitmentdependent interaction strength. Ecol. Monogr., 69 (1999) 277-296.

Connolly, S.R., Menge, B.A. and Roughgarden, J., A latitudinal gradient in recruitment of intertidal invertebrates in the northeast Pacific Ocean. Ecology, 82 (2001) 1799-1813.

Criales, M.M. and Anger, K., Experimental studies on the larval development of the shrimps Crangon crangon and C. allmanni. Helgoländer Meeresunters., 40 (1986) $241-$ 265.

Criales, M.M., Wang, J.D., Browder, J.A., Robblee, M.B., Jackson, T.L. and Hittle, C., Variability in supply and cross-shelf transport of pink shrimp (Farfantepenaeus duorarum) postlarvae into western Florida Bay. Fish. Bull. U.S., 104 (2006) 60-74.

Crisp, D.J., Factors influencing the settlement of marine invertebrate larvae. In: Chemoreception in Marine Organisms, Grant, P.T. and Mackie, A.M. (eds.). Academic Press, London, 1974, pp. 177-267.

Cruz, T., Castro, J.J., Delany, J., McGrath, D., Myers, A.A., O’Riordan, R.M., Power, A.-M., Rabaca, J. and Hawkins, S.J., Tidal rates of settlement of the intertidal barnacles Chthamalus stellatus and Chthamalus montagui in western Europe: the influence of the night/day cycle. J. exp. mar. Biol. Ecol., 318 (2005) 51-60.

Cunningham, C.W., Blackstone, N.W. and Buss, L.W., Evolution of king crabs from hermit crab ancestors. Nature, 355 (1992) 539-542.

Dahms, H.U., Phylogenetic implications of the Crustacean nauplius. Hydrobiologia, 417 (2000) 91-99.

Dall, W., Hill, B.J., Rothlisberg, P.C. and Staples, D.J., The Biology of the Penaeidae. Adv. mar. Biol., 27 (1990) $1-461$.

Day, R. and McEdward, L., Aspects of the physiology and ecology of pelagic larvae of marine benthic invertebrates. In: Marine Plankton Life Cycle Strategies, Steidinger, K.A. and Walker, L.M. (eds.), CRC Press, Boca Raton, FL, 1984, pp. 94-120.

de Queiroz, A., The resurrection of oceanic dispersal in historical biogeography. Trends Ecol. Evol., 20 (2005) 68-73.

Delany, J., Myers, A.A., Mcgrath, D., O’Riordan, R.M. and Power, A.M., Role of post-settlement mortality and 'supply-side' ecology in setting patterns of intertidal distribution in the chthamalid barnacles Chthamalus montagui and C. stellatus. Mar. Ecol. Prog. Ser., 249 (2003) 207-214.

deRivera, C.E., Ruiz, G.M., Hines, A.H. and Jivoff, P., Biotic resistance to invasion: native predator limits abundance and distribution of an introduced crab. Ecology, 86 (2005) 3364-3376.

Dobkin, S., Early developmental stages of pink shrimp, Penaeus duorarum, from Florida waters. Fish. Bull. U.S., 61 (1961) 321-349.

Drach, P., Mue et cycle d'intermue chez les Crustacés décapodes. Annls. Inst. Océanogr., Monaco, 19 (1939) 103-391.

Eckert, G.L., Effects of the planktonic period on marine population fluctuations. Ecology, 84 (2003) 372-383.

Epelbaum, A.B. and Kovatcheva, N.P., Daily food intakes and optimal food concentrations for red king crab (Paralithodes camtschaticus) larvae fed Artemia nauplii under laboratory conditions. Aquaculture Nutr., 11 (2005) 455-461.

Ernst, B., Orensanz, J.M. and Armstrong, D.A., Spatial dynamics of female snow crab (Chionoecetes opilio) in the eastern Bering Sea. Can. J. Fish. Aquat. Sci., 62 (2005) 250-268.

Etherington, L.L. and Eggleston, D.B., Spatial dynamics of large-scale, multistage crab (Callinectes sapidus) dispersal: determinants and consequences for recruitment. Can. J. Fish. Aquat.Sci., 60 (2003) 873-887.

Evans, K.L., Warren, P.H. and Gaston, K.J., Species-energy relationships at the macroecological scale: a review of the mechanisms. Biol. Rev., 80 (2005) 1-25.

Feder, M.E., Bennett, A.F. and Huey, R.B., Evolutionary physiology. Ann. Rev. Ecol. Syst., 31 (2000) 315-341.

Felder, D.L., Martin, J.W. and Goy, J.W., Patterns in early postlarval development of Decapods. In: Larval Growth, Crustacean Issues, Vol. 2, Wenner, A.M. (ed.), Balkema, Rotterdam, 1985, pp. 163-225.

Feldmann, R.M., Interpreting ecology and physiology of fossil decapod crustaceans. Contr. Zool., 72 (2003) 111117.

Fielder, D.R., Greenwood, J.G. and Ryall, J.C., Larval development of the tiger prawn, Penaeus esculentus Haswell, 1879 (Decapoda, Penaeidae) reared in the laboratory. Austr. J. mar. Freshw. Res., 26 (1975) 155-175.

Fincham, A.A., Larval development of British prawns and shrimps (Crustacea, Decapoda, Natantia). 4. Palaemon (Palaemon) serratus (Pennant, 1777) and functional morphology of swimming. Bull. Br. Mus. nat. Hist. (Zool.), 44 (1983) 125-161.

Forward, R.B. and Rittschof, D., Alteration of photoresponses involved in diel vertical migration of a crab larva by fish mucus and degradation products of mucopolysaccharides. J. exp. mar. Biol. Ecol., 245 (2000) 277-292.

Forward, R.B., Tankersley, R.A. and Rittschof, D., Cues for metamorphosis of brachyuran crabs: an overview. Am. Zool., 41 (2001) 1108-1122.

Fraschetti, S., Giangrande, A., Terlizzi, A. and Boero, F., Pre- and post-settlement events in benthic community dynamics. Oceanologica Acta, 25 (2002) 285-295.

Frenot, Y., Chown, S.L., Whinam, J., Selkirk, P.M., Convey, 
P., Skotnicki, M. and Bergstrom, D.M., Biol. Invasions in the Antarctic: extent, impacts and implications. Biol. Rev., 80 (2005) 45-72.

Garcia-Berthou, E., Alcaraz, C., Pou-Rovira, Q., Zamora, L., Coenders, G. and Feo, C., Introduction pathways and establishment rates of invasive aquatic species in Europe. Can. J. Fish. Aquat. Sci., 62 (2005) 453-463.

Gardner, C., Maguire, G.B. and Williams, H., Effects of water temperature and thermoclines on larval behaviour and development in the giant crab Pseudocarcinus gigas (Lamarck). J. Plankton Res., 26 (2004) 393-402.

Gebauer, P., Paschke, K. and Anger, K., Metamorphosis in a semiterrestrial crab, Sesarma curacaoense: intra- and interspecific settlement cues from adult odors. J. exp. mar. Biol. Ecol., 268 (2002) 1-12.

Gebauer, P., Paschke, K. and Anger, K., Delayed metamorphosis in Decapod Crustaceans: evidence and consequences. Rev. Chil. Hist. nat., 76 (2003) 169-175.

George, R.W., Evolution of life cycles, including migration, in spiny lobsters (Palinuridae). N.Z. J. mar. Freshw. Res., 39 (2005) 503-514.

Gherardi, F. and Daniels, W.H., Agonism and shelter competition between invasive and indigenous crayfish species. Can. J. Zool, 82 (2004) 1923-1932.

Gilbert, S.F., Ecological developmental biology: developmental biology meets the real world. Devel. Biol., 233 (2001) 1-12.

Giménez, L., Potential effects of physiological plastic responses to salinity on population networks of the estuarine crab Chasmagnathus granulata. Helgol. Mar. Res., 56 (2003) 265-273.

Giménez, L., Marine community ecology: importance of trait-mediated effects propagating through complex life cycles. Mar. Ecol. Prog. Ser., 283 (2004) 303-310.

Giménez, L. and Anger, K., Larval performance in an estuarine crab, Chasmagnathus granulata, is a consequence of both larval and embryonic experience. Mar. Ecol. Prog. Ser., 249 (2003) 251-264.

Gimenez, L. and Anger, K., Effects of temporary food limitation on survival and development of brachyuran crab larvae. J. Plankton Res., 27 (2005) 485-494.

Giménez, L., Anger, K. and Torres, G., Linking life history traits in successive phases of a complex life cyle: effects of larval biomass on early juvenile development in an estuarine crab, Chasmagnathus granulata. Oikos, 104 (2004) 570-580.

Graham, A., Geohistory models and Cenozoic paleoenvironments of the Caribbean region. Syst. Bot., 28 (2003) 378-386.

Grantham, B.A., Eckert, G.L. and Shanks, A.L., Dispersal potential of marine invertebrates in diverse habitats. Ecol. Appl., 13 (2003) S108-S116.

Greenaway, P., Physiological diversity and the colonization of land. In: Crustaceans and the Biodiversity Crisis, 1, Schram, F.R. and von Vaupel Klein (eds.), J.C. Koninklijke Brill NV, Leiden, The Netherlands, 1999, pp. 823-842.

Groeneveld, J.C. and Branch, G.M., Long-distance migration of South African deep-water rock lobster Palinurus gilchristi. Mar. Ecol. Prog. Ser., 232 (2002) 225-238.
Gurney, R., Bibliography of the Larvae of Decapod Crustacea. Ray Society, London, 1939.

Haeckel, E., Generelle Morphologie der Organismen: Allgemeine Grundzüge der organischen Formen. Wissenschaft, mechanisch begründet durch die von Charles Darwin reformirte Descendenz-Theorie. 1. Georg Riemer, Berlin, 1866.

Halanych, K.M., The new view of animal phylogeny. Ann. Rev. Ecol. Evol. Syst., 35 (2004) 229-256.

Hall, B.K. and Wake, M.H., The Origin and Evolution of Larval Forms. Academic Press, San Diego, 1999.

Hamer, J.P., McCollin, T.A. and Lucas, I.A.N., Viability of decapod larvae in ships' ballast water. Mar. Poll. Bull., 36 (1998) 646-647.

Harms, J., Larval development and delayed metamorphosis in the hermit crab Clibanarius erythropus (Latreille) (Crustacea, Diogenidae). J. exp. mar. Biol. Ecol., 156 (1992) 151-160.

Harms, J., The neozoan Elminius modestus Darwin (Crustacea, Cirripedia): possible explanations for its successful invasion in European water. Helgoländer Meeresunters, 52 (1998) 337-345.

Harms, J. and Anger, K., Settlement of the barnacle Elminius modestus Darwin on test panels at Helgoland (North Sea): a ten year study. Scient. Mar., 53 (1989) 417-421.

Hartnoll, R.G., Growth in Crustacea - twenty years on. Hydrobiologia, 449 (2001) 111-122.

Harvey, A.W., Delayed metamorphosis in Florida hermit crabs: multiple cues and constraints (Crustacea: Decapoda: Paguridae and Diogenidae). Mar. Ecol. Prog. Ser., 141 (1996) 27-36.

Hastings, A., Cuddington, K., Davies, K.F., Dugaw, C.J., Elmendorf, S., Freestone, A., Harrison, S., Holland, M., Lambrinos, J., Malvadkar, U., Melbourne, B.A., Moore, K., Taylor, C. and Thomson, D., The spatial spread of invasions: new developments in theory and evidence. Ecol. Letters, 8 (2005) 91-101.

Havenhand, J.N., Evolutionary ecology of larval types. In: Ecology of Marine Invertebrate Larvae, McEdward, L.R. (ed.), CRC Press, Boca Raton, 1995, pp. 79-122.

Hedges, S.B., Vicariance and dispersal in Caribbean biogeography. Herpetologica, 52 (1996) 466-473.

Herborg, L.-M., Rushton, S.P., Clare, A.S. and Bentley, M.G., Spread of the Chinese mitten crab (Eriocheir sinensis H. Milne Edwards) in Continental Europe: analysis of a historical data set. Hydrobiologia, 503 (2003) 21-28.

Høeg, J.T., The biology and life-cycle of the rhizocephala (Cirripedia). J. mar. biol. Ass. U.K., 75 (1995) 517-550.

Hong, S.Y., Development of epipods and gills in some pagurids and brachyurans. J. nat. Hist., 22 (1988) 10051040.

Hoßfeld, U. and Olsson, L., The road from Haeckel: The Jena tradition in evolutionary morphology and the origins of “Evo-Devo". Biol. Philos., 18 (2003) 285-307.

Howard, S.C. and Hentschel, B.T., Effects of short-term food variability on the plasticity of age and size at metamorphosis of porcelain crab larvae. Limnol. Oceanogr., 50 (2005) 1960-1971.

Hughes, T.P., Baird, A.H., Dinsdale, E.A., Moltschaniwskyj, 
N.A., Pratchett, M.S., Tanner, J.E. and Willis, B.L., Supplyside ecology works both ways: the link between benthic adults, fecundity, and larval recruits. Ecology, 81 (2000) 2241-2249.

Ingle, R.W., Decapod larval taxonomic research in the North Eastern Atlantic and Mediterranean: past achievements and future prospects. Invert. Reprod. Develop., 33 (1998) 97-107.

Jablonski, D., Evolutionary rates and modes in late Cretaceous gastropods: role of larval ecology. Third North American Palaeontological Convention Proceedings, 1 (1982) 257-262.

Jarrett, J.N., Seasonal variation in larval condition and postsettlement performance of the barnacle Semibalanus balanoides. Ecology, 84 (2003) 384-390.

Jeffs, A.G., Montgomery, J.C. and Tindle, C.T., How do spiny lobster post-larvae find the coast? N.Z. J. Mar. Freshw. Res., 39 (2005) 605-617.

Jenkins, S.R. and Hawkins, S.J., Barnacle larval supply to sheltered rocky shores: a limiting factor? Hydrobiologia, 503 (2003) 143-151.

Kingsford, M.J., Leis, J.M., Shanks, A., Lindeman, K.C., Morgan, S.G. and Pineda, J., Sensory environments, larval abilities and local self-recruitment. Bull. Mar. Sci., 70 (2002) 309-340.

Kinne, O., Non-genetic adaptation to temperature and salinity. Helgoländer wiss. Meeresunters., 9 (1964) 433 458.

Kinne, O., Physiology of estuarine organisms with special referance to salinity and temperature: general aspects. In: Estuaries, Publ. Amer. Ass. Adv. Sci., Vol. 83, Lauff, H.H. (ed.), American Association for the Advancement of Science, Washington, DC, 1967, pp. 525-540.

Knowlton, R.E. and Vargo, C.K., The larval morphology of Palaemon floridanus Chace, 1942 (Decapoda, Palaemonidae) compared with other species of Palaemon and Palaemonetes. Crustaceana, 77 (2004) 683-715.

Ko, H.S., An, H.S. and Sulkin, S., Zoeal development of Palapedia integra (Decapoda: Brachyura: Xanthidae) reared in the laboratory. J. Crust. Biol., 24 (2004) 637651.

Konishi, K. and Quintana, R., Notes on the prezoea stage of decapod crustaceans. Aquabiology 52, (1987) 372-378.

Labandeira, C. and Beall, B.S., Arthropod terrestriality. In: Arthropod Palaeobiology, Short Courses in Palaeontology, Vol. 3, Mikulic, D. and Culver, S.J. (eds.), The Palaeontological Society, Knoxville, Tenn., USA, 1990, pp. 214-232.

Lam, S.C., Abbreviated development of non-marine crab, Sesarma (Geosesarma) perracae (Brachyura; Grapsidae), from Singapore. J. Zool., Lond., 158 (1969) 357370.

Lawson, J., Davenport, J. and Whitaker, A., Barnacle distribution in Lough Hyne Marine Nature Reserve: a new baseline and an account of invasion by the introduced Australasian species Elminius modestus Darwin. Est. Coast. Shelf Sci., 60 (2004) 729-735.

Leach, W.E., Malacostraca Podophthalmata Britanniae; or descriptions of British species of Crabs, Lobsters, Prawns, and of other Malacostracas with pedunculated eyes. Illustrated with colored figures of all species, by James Sowerby, F.L.S. G.S. \& W.S. \&c. London, James Sowerby. 14 (1817) pls 16, 25, 44 [for dates of publication see Rathbun, 1897].

Lee, C.E. and Bell, M.A., Causes and consequences of recent freshwater invasions by saltwater animals. Trends Ecol. Evol., 14 (1999) 284-288.

Lewis, C.A., A review of substratum selection in free-living and symbiotic cirripeds. In: Settlement and Metamorphosis of Marine Invertebrates Larvae, Chia, F.S. and Rice, M.E., Elsevier North-Holland, New York, 1978, pp. 207-218.

Linck, B.M., Einfluß von Temperatur und Salzgehalt auf die Larven der Nordseegarnele Crangon crangon. M.Sc. Thesis, University Oldenburg, Germany, 1995.

Little, C.,The Terrestrial Invasion: an Ecophysiological Approach to the Origins of Land Animals. Cambridge University Press, Cambridge, U.K., 1990.

Lohrer, A.M., Fukui, Y., Wada, K. and Whitlatch, R.B., Structural complexity and vertical zonation of intertidal crabs, with focus on habitat requirements of the invasive Asian shore crab, Hemigrapsus sanguineus (de Haan). J. exp. mar. Biol. Ecol., 244 (2000) 203-217.

Lovrich, G.A., Thatje, S., Calcagno, J.A., Anger, K. and Kaffenberger, A., Changes in biomass and chemical composition during lecithotrophic larval development of the southern king crab, Lithodes santolla (Molina). J. exp. mar. Biol. Ecol., 288 (2003) 65-79.

Luppi, T.A., Spivak, E.D., Anger, K. and Valero, J.L., Patterns and processes of Chasmagnathus granulata and Cyrtograpsus angulatus (Brachyura: Grapsidae) recruitment in Mar Chiquita Coastal Lagoon, Argentina. Est. Coast. Shelf Sci., 55 (2002) 287-297.

Luppi, T.A., Spivak, E.D. and Bas, C.C., The effects of temperature and salinity on larval development of Armases rubripes Rathbun, 1897 (Brachyura, Grapsoidea, Sesarmidae), and the southern limit of its geographical distribution. Est. Coast. Shelf Sci., 58 (2003) 575-585.

Maas, A. and Waloßek, D., Larval development of Euphausia superba Dana, 1852 and a phylogenetic analysis of the Euphausiacea. Hydrobiologia, 448 (2001) 143-169.

Mack, R.N., Simberloff, D., Lonsdale, W.M., Evans, H., Clout, M. and Bazzaz, F.A., Biotic invasions: causes, epidemiology, global consequences, and control. Ecol. Appl., 10 (2000) 689-710.

Manzanilla-Dominguez H. and Gasca R., Distribution and abundance of phyllosoma larvae (Decapoda, Palinuridae) in the southern Gulf of Mexico and the western Caribbean Sea. Crustaceana, 77 (2004) 75-93.

Marques, F. and Pohle, G., Phylogenetic analysis of the Pinnotheridae (Crustacea, Brachyura) based on larval morphology, with emphasis on the Dissodactylus species complex. Zool. Scripta, 24 (1995) 347-364.

Marques, F. and Pohle, G., The use of structural reduction in phylogenetic reconstruction of decapods and a phylogenetic hypothesis for 15 genera of Majidae: testing previous larval hyptheses and assumptions. Invert. Reprod. Develop., 33 (1998) 241-262.

Marques, F.P.L. and Pohle, G., Searching for larval support 
for majoid families (Crustacea: Brachyura) with parti-cular reference to Inachoididae Dana, 1851. Invert. Reprod. Develop., 43 (2003) 71-82.

Martin, J.W., Phylogenetic significance of the brachyuran megalopa: evidence from the Xanthidae. In: Symposia of the Zoological Society of London, Vol. 59, Fincham, A.A. and Rainbow, P.S. (eds.), Clarendon Press, Oxford, 1988, pp. 69-102.

Martin, J.W. and Davis, G.E., Updated Classification of the Recent Crustacea. Crustacean Classification Project, Natural History Museum of Los Angeles County, Los Angeles, CA, 2001.

Mashiko, K. and Numachi, K.-I., Derivation of populations with different-sized eggs in the palaemonid prawn Macrobrachium nipponense. J. Crust. Biol., 20 (2000) 118-127.

McEdward, L.R. (ed.), Ecology of Marine Invertebrate Larvae. CRC Press, Boca Raton, FL, 1995.

McEdward, L.R., Adaptive evolution of larvae and life cycles. Seminars Cell Devel. Biol., 11 (2000) 403-409.

McKenney, C.L., The influence of insect juvenile hormone agonists on metamorphosis and reproduction in estuarine crustaceans. Integr. Comp. Biol., 45 (2005) 97-105.

McLaughlin, P.A. and Lemaitre, R., Carcinization in the Anomura - fact or fiction? I. Evidence from adult morphology. Contr. Zool., 67 (1997) 79-123.

McLaughlin, P.A., Lemaitre, R. and Tudge, C.C., Carcinization in the Anomura - fact or fiction? II. Evidence from larval, megalopal and early juvenile morphology. Contr. Zool., 73 (2004) 165-205.

Menge, B.A., Recruitment vs. postrecruitment processes as determinants of barnacle population abundance. Ecol. Monogr., 70 (2000) 265-288.

Menshenina, L.L., Some correlations of limb development in Euphausia larvae (Euphausiacea). Crustaceana, 58 (1990) 1-16.

Milne Edwards, H., Histoire naturelle des Crustacés, comprenant l'Anatomie, la Physiologie et la Classification de ces Animaux. Libraire Encyclopédique de Roret 1. Paris, 1834.

Moksnes, P.O., Interference competition for space in nursery habitats: density-dependent effects on growth and dispersal in juvenile shore crabs Carcinus maenas. Mar. Ecol. Prog. Ser., 281 (2004) 181-191.

Moksnes, P.-O., Hedvall, O. and Reinwald, T., Settlement behavior in shore crabs Carcinus maenas: why do postlarvae emigrate from nursery habitats? Mar. Ecol. Prog. Ser., 250 (2003) 215-230.

Mooney, H.A. and Hobbs, R.J., Invasive species in a changing world. Island Press, Washington, D.C., 2000.

Morgan, S.G., Life and death in the plankton: larval mortality and adaptation. In: Ecology of Marine Invertebrate Larvae, McEdward, L.R. (ed.), CRC Press, Boca Raton, FL, 1995, pp. 279-321.

$\mathrm{Mu}, \mathrm{X}$. and Leblanc, G.A., Cross communication between signaling pathways: Juvenoid hormones modulate ecdysteroid activity in a crustacean. J. exp. Zool., 301A (2004) 793-801.

Müller, F., Für Darwin. Engelmann, Leipzig, 1864.

Murphy, N.P. and Austin, C.M., Phylogenetic relationships of the globally distributed freshwater prawn genus Macrobrachium (Crustacea: Decapoda: Palaemonidae): biogeography, taxonomy and the convergent evolution of abbreviated larval development. Zoologica Scripta, 34 (2005) 187-197.

Nagaraj, M., Combined effects of temperature and salinity on the zoeal development of the green crab, Carcinus maenas (Linnaeus, 1758) (Decapoda: Portunidae). Sci. Mar., 57 (1993) 1-8.

Ng, P.K.L. and Clark, P.F., The eumedonid file: a case study of systematic compatibility using larval and adult characters (Crustacea: Decapoda: Brachura). Invert. Reprod. Develop., 38 (2000a) 225-252.

Ng, P.K.L. and Clark, P.F., The Indo-Pacific Pilumnidae XII. On the familial placement of Chlorodiella bidentata (Nobili, 1901) and Tanaocheles stenochilus Kropp, 1984 using adult and larval characters with the establishment of a new subfamily, Tanaochelinae (Crustacea: Decapoda: Brachyura). J. nat. Hist., 34 (2000b) 207-245.

Ng, T.Y.T. and Keough, M.J., Delayed effects of larval exposure to $\mathrm{Cu}$ in the bryozoan Watersipora subtorquata. Mar. Ecol. Prog. Ser., 257 (2003) 77-85.

Nijhout, F.H., Hormonal control in larval development insects. In: The Origin and Evolution of Larval Forms, Hall, B.K. and Wake, M.H. (eds.), Academic Press, San Diego, 1999, pp. 217-254.

Nogata, Y., Yoshimura, E., Shinshima, K., Kitano, Y. and Sakaguchi, I., Antifouling substances against larvae of the barnacle Balanus amphitrite from the marine sponge, Acanthella cavernosa. Biofouling, 19 (2003) 193-196.

Nylund, G.M. and Pavia, H., Inhibitory effects of red algal extracts on larval settlement of the barnacle Balanus improvisus. Mar. Biol., 143 (2003) 875-882.

Paglianti, A. and Gherardi, F., Combined effects of temperature and diet on growth and survival of young-of-year crayfish: a comparison between indigenous and invasive species. J. Crust. Biol., 24 (2004) 140-148.

Palumbi, S.R., Genetic divergence, reproductive isolation, and marine speciation. Ann. Rev. Ecol. Syst., 25 (1994) 547-572.

Park, S., Epifanio, C.E. and Iglay, R.B., Patterns of larval release by the Asian shore crab Hemigrapsus sanguineus (de Haan): periodicity at diel and tidal frequencies. J. Shellfish Res., 24 (2005) 591-595.

Pechenik, J.A., Delayed metamorphosis by larvae of benthic marine invertebrates: Does it occur? Is there a price to pay? Ophelia, 32 (1990) 63-94.

Pechenik, J.A., On the advantages and disadvantages of larval stages in benthic marine invertebrate life cycles. Mar. Ecol. Prog. Ser., 177 (1999) 269-297.

Pechenik, J.A., Wendt, D.E. and Jarrett, J.N., Metamorphosis is not a new beginning. BioScience, 48 (1998) 901-910.

Pedersen, O.P., Aschan, M., Rasmussen, T., Tande, K.S. and Slagstad, D., Larval dispersal and mother populations of Pandalus borealis investigated by a Lagrangian particletracking model. Fish. Res., 65 (2003) 173-190.

Perez Farfante, I. and Kensley B., Penaeoid and Sergestoid Shrimps and Prawns of the World. Keys and Diagnoses for the Families and Genera. Mém. Mus. natn. Hist. nat. Paris, 175 (1997) 1-223. 
Phillips, N.E., Variable timing of larval food has consequences for early juvenile performance in a marine mussel. Ecology, 85 (2004) 2341-2346.

Piersma, T. and Drent, J., Phenotypic flexibility and the evolution of organismal design. Trends Ecol. Evol., 18 (2003) 228-233.

Pigliucci, M., Evolution of phenotypic plasticity: where are we going now? Trends Ecol. Evol., 20 (2005) 481-486.

Pohle, G. and Marques, F., Phylogeny of the Pinnotheridae: larval and adult evidence, with emphasis on the evolution of gills. Invert. Reprod. Develop., 33 (1998) 229-239.

Pohle, G. and Marques, F., Larval stages of Paradasygyius depressus (Bell, 1835) (Crustacea: Decapoda: Brachyura: Majidae) and a phylogenetic analysis for 21 genera of Majidae. Proc. Biol. Soc. Wash., 113 (2000) 739-760.

Pörtner, H.O., Climate variations and the physiological basis of temperature dependent biogeography: systemic to molecular hierarchy of thermal tolerance in animals. Comp. Biochem. Physiol., 132A (2002) 739-761.

Queiroga, H. and Blanton, J., Interactions between behaviour and physical forcing in the control of horizontal transport of decapod crustacean larvae. Adv. mar. Biol., 47 (2005) 107-214.

Rabalais, N.N. and Gore, R.H., Abbreviated development in Decapods. In: Larval Growth, Crustacean Issues, Vol. 2, Wenner, A.M. (ed.), Balkema, Rotterdam, 1985, pp. 67126.

Rathbun, M.J., A revision of the nomenclature of the Brachyura. Proc. Biol. Soc. Wash. 11 (1897) 153-167.

Rice, A.L., Plea for improved standards in descriptions of crab zoeae. Crustaceana, 37 (1979) 214-218.

Rice, A.L., Crab zoeal morphology and its bearing on the classification of the Brachyura. Trans. Zool. Soc. Lond., 35 (1980) 271-424.

Rice, A.L., Crab zoeae and brachyuran classification: a reappraisal. Bull. Br. Mus. nat. Hist. (Zool.), 40 (1981) 287-296.

Rice, A.L., Zoeal evidence for brachyuran phylogeny. In: Crustacean phylogeny, Crustacean Issues, Vol. 1, Schram, F.R. (ed.), Balkema, Rotterdam, 1983, pp. 313329.

Rice, A.L., The megalopa stage in majid crabs, with a review of spider crab relationships based on laval characters. In: Aspects of Decapod Crustacean Biology, Symp. Zool. Soc. Lond., Vol. 59, Fincham, A.A. and Rainbow, P.S. (eds.), Clarendon Press, Oxford, 1988, pp. 27-46.

Rice, A.L., Two centuries of larval crab papers: a preliminary analysis. In: History of Carcinology, Crustacean Issues, Vol. 8, Truesdale, F. (ed.), Balkema, Rotterdam, 1993, pp. 285-292.

Rittschof, D., Forward, R.B., Cannon, G., Welch, J.M., McClary, M., Holm, E.R., Clare, A.S., Conova, S., McKelvey, L.M., Bryan, P., van-Dover, C.L., Clare, A.S., Fusetani, N. and Jones, M.B., Cues and context: larval responses to physical and chemical cues. Biofouling, 12 (1998) 31-44.

Rosenberg, R. and Costlow, J.D., Delayed response to irreversible non-genetic adaptation to salinity in early development of the brachyuran crab Rhithropanopeus harrisii, and some notes on adaptation to temperature. Ophelia, 18 (1979) 97-112.
Ross, P.M., Larval supply, settlement and survival of barnacles in a temperate mangrove forest. Mar. Ecol. Prog. Ser., 215 (2001) 237-249.

Roth, B.M. and Kitchell, J.F., The role of size-selective predation in the displacement of Orconectes crayfishes following rusty crayfish invasion. Crustaceana, 78 (2005) 297-310.

Rotllant, G., Anger, K., Durfort, M. and Sardà, F., Elemental and biochemical composition of Nephrops norvegicus (Linnaeus 1758) larvae from the Mediterranean and Irish Seas. Helgoland. Mar. Res., 58 (2004) 206-210.

Roughgarden, J., Evolution of the niche width. Am. Natur., 106 (1972) 683-718.

Roughgarden, J., The evolution of marine life cycles. In: Mathematical Evolutionary Theory, Vol. 12, Feldman, M.W. Procenton Univ. Press, 1989, pp. 270-300.

Rudnick, D., Veldhuizen, T., Tullis, R., Culver, C., Hieb, K. and Tsukimura, B., A life history model for the San Francisco Estuary population of the Chinese mitten crab, Eriocheir sinensis (Decapoda: Grapsoidea). Biol. Invasions, 7 (2005) 333-350.

Ruiz, G.M., Fofonoff, P.W., Carlton, J.T., Wonham, M.J. and Hines, A.H., Invasion of coastal marine communities in North America: apparent patterns, processes, and biases. Ann. Rev. Ecol. Syst., 31 (2000) 481-531.

Rumrill, S.S., Natural mortality of marine invertebrate larvae. Ophelia, 32 (1990) 163-198.

Rumsey, S.M. and Franks, P.J.S., Influence of variability in larval development on recruitment success in the euphausiid Euphausia pacifica: elasticity and sensitivity analyses. Mar. Biol., 133 (1999) 283-291.

Rundle, H.D. and Nosil, P., Ecological speciation. Ecol. Letters, 8 (2005) 336-352.

Saigusa, M., Okochi, T. and Ikei, S., Nocturnal occurrence, and synchrony with tidal and lunar cycles, in the invertebrate assemblage of a subtropical estuary. Acta Oecol., 24 (2003) S191-S204.

Santana, W., Pohle, G. and Marques, F., Larval development of Apiomithrax violaceus (A. Milne Edwards, 1868) (Decapoda: Brachyura: Majoidea: Pisidae) reared in laboratory conditions, and a review of larval characters of Pisidae. J nat. Hist., 38 (2004) 1773-1797.

Scheltema, R.S., On dispersal and planktonic larvae of benthic invertebrtaes: an eclectic overview and summary of problems. Bull. mar. Sci., 39 (1986) 290-322.

Scholtz, G., Evolution of the nauplius stage in malacostracan crustaceans. J. Zool. Syst. Evol. Res., 38 (2000) 175187.

Scholtz, G., (ed.) Evolutionary Developmental Biology of Crustacea. Crustacean Issues 15. A.A. Balkema, Leiden, The Netherlands, 2003.

Scholtz, G. and Richter, S., Phylogenetic systematics of the reptantian Decapoda (Crustacea, Malacostraca). Zool. J. Linn. Soc., 113 (1995) 289-328.

Schubart, C.D. and Diesel, R., Osmoregulation and the transition from marine to freshwater and terrestrial life: a comparative study of Jamaican crabs of the genus Sesarma. Arch. Hydrobiol., 145 (1999) 331-347.

Schubart, C.D. and Koller, P., Genetic diversity of freshwater crabs (Brachyura: Sesarmidae) from central Jamaica with description of a new species. J. nat. Hist., 
39 (2005) 469-481.

Schubart, C.D., Diesel, R. and Hedges, S.B., Rapid evolution to terrestrial life in Jamaican crabs. Nature, 393 (1998) 363-365.

Shanks, A.L., Largier, J. and Brubaker, J., Observations on the distribution of meroplankton during an upwelling event. J. Plankton Res., 25 (2003) 645-667.

Silas, E.G. and Mathew, K.J., A critique to the study of larval development in Euphausiacea. In: Proc. Symp. Warm Water Zooplankton. Dona Paula, Goa, India: Natl. Inst. Oceanography, 1977.

Spicer, J.I. and Burggren, W.W., Development of physiological regulatory systems: altering the timing of crucial events. Zoology, 106 (2003) 91-99.

Spindler, K.-D. and Anger, K., Ecdysteroid levels during the larval development of the spider crab Hyas araneus. Gen. Comp. Endocrinol., 64 (1986) 122-128.

Stevens, B.G. and Swiney, K.M., Post-settlement effects of habitat type and predator size on cannibalism of glaucothoe and juveniles of red king crab Paralithodes camtschaticus. J. exp. mar. Biol. Ecol., 321 (2005) 1-11.

Strasser, K.M. and Felder, D.L., Effects of salinity on development in the ghost shrimp Callichirus islagrande and two populations of C. major (Crustacea: Decapoda: Thalassinidea). Gulf Caribb. Res., 13 (2001) 9-18.

Strasser, M. and Günther, C.-P., Larval supply of predator and prey: temporal mismatch between crabs and bivalves after a severe winter in the Wadden Sea. J. Sea Res., 46 (2001) 57-67.

Strathmann, R.R., Selection for retention or export of larvae in estuaries. In: Estuarine Comparisons, Kennedy, V.S. (ed.), Academic Press, San Diego, 1982, pp. 521-535.

Strathmann, R.R., Hypotheses on the origins of marine larvae. Ann. Rev. Ecol. Syst., 24 (1993a) 89-117.

Strathmann, R.R., Review of "Larvae and Evolution. Toward a New Zoology”. Q. Rev. Biol., 68 (1993b) 280-282.

Strathmann, R.R., Hughes, T.P., Kuris, A.M., Lindeman, K.C., Morgan, S.G., Pandolfi, J.M. and Warner, R.R., Evolution of local recruitment and its consequences for marine populations. Bull. mar. Sci., 70 (2002) 377-396.

Svensson, C.J., Jenkins, S.R., Hawkins, S.J., Myers, A.A., Range, P., Paula, J., O’Riordan, R.M. and Aberg, P., Models of open populations with space-limited recruitment in stochastic environments: relative importance of recruitment and survival in populations of Semibalanus balanoides. Mar. Ecol. Prog. Ser., 275 (2004) 185-197.

Swearer, S.E., Shima, J.S., Hellberg, M.E., Thorrold, S.R., Jones, G.P., Robertson, D.R., Morgan, S.G., Selkoe, K.A., Ruiz, G.M. and Warnerages, R.R., Evidence of self-recruitment in demersal marine populations. Bull. mar. Sci., 70 (2002) 251-271.

Tankersley, R.A., Bullock, T.M., Forward, R.B. and Rittschof, D., Larval release behaviors in the blue crab Callinectes sapidus: role of chemical cues. J. exp. mar. Biol. Ecol., 273 (2002a) 1-14.

Tankersley, R.A., Welch, J.M. and Forward, R.B., Settlement times of blue crab (Callinectes sapidus) megalopae during flood-tide transport. Mar. Biol., 141 (2002b) 863875.

Thatje, S., The future fate of the Antarctic marine biota? Trends Ecol. Evol., 20 (2005) 418-419.
Thatje, S., Anger, K., Calcagno, J.A., Lovrich, G.A., Pörtner, H.O. and Arntz, W.E., Challenging the cold: crabs reconquer the Antarctic. Ecology, 86 (2005) 619-625.

Thiyagarajan, V., Hung, O.S., Chiu, J.M.Y., Wu, R.S.S. and Qian, P.Y., Growth and survival of juvenile barnacle Balanus amphitrite: interactive effects of cyprid energy reserve and habitat. Mar. Ecol. Prog. Ser., 299 (2005) 229-237.

Thompson, J.V., On the metamorphoses of the Crustacea, and on the zoea, exposing their singular structure, and demonstrating that they are not, as has been supposed, a peculiar genus, but the larva of Crustacea. In: Zoological Researches; or Natural History of nondiscript or imperfectly known animals, in a series of memoirs. Memoir I, 1, Cork, Ireland, 1828, pp. 1-11.

Thorson, G., Reproduction and larval development of Danish marine bottom invertebrates. Meddr. Kommn. Havunders (Plankton), 4 (1946) 1-523.

Thorson, G., Reproductive and larval ecology of marine bottom invertebrates. Biol. Rev., 25 (1950) 1-45.

Thorson, G., Length of pelagic larval life in marine bottom invertebrates as related to larval transport by ocean currents. Publs. Am. Ass. Advmt. Sci., 67 (1961) 455474.

Thresher, R., Proctor, C., Ruiz, G., Gurney, R., MacKinnon, C., Walton, W., Rodriguez, L. and Bax, N., Invasion dynamics of the European shore crab, Carcinus maenas, in Australia. Mar. Biol., 142 (2003) 867-876.

Tilburg, C.E., Reager, J.T. and Whitney, M.M., The physics of blue crab larval recruitment in Delaware bay: a model study. J. mar. Res., 63 (2005) 471-495.

Tuberty, S.R. and McKenney, C.L., Ecdysteroid responses of estuarine crustaceans exposed through complete larval development to juvenile hormone agonist insecticides. Integr. Comp. Biol., 45 (2005) 106-117.

Waloßek, D., The Upper Cambrian Rehbachiella and significance the phylogeny of Branchiopoda and Crustacea. Fossils Strata, 32 (1993) 1-202.

Waloßek, D., Høeg, J.T. and Shirley, T.C., Larval development of the rhizocephalan cirripede Briarosaccus tenellus (Maxillopoda: Thecostraca) reared in the laboratory: a scanning electron microscopy study. Hydrobiologia, 328 (1996) 9-47.

Waloßek, D. and Müller, K.J., Upper Cambrian stem-lineage crustaceans and their bearing upon the monophyletic origin of Crustacea and the position of Agnostus. Lethaia, 23 (1990) 407-427.

Waloßek, D. and Müller, K.J., Cambrian 'Orsten'-type arthropods and the phylogeny of Crustacea. In: Arthropod Relationships, Systematics Association, Special Vol. Ser., 55, Fortey, R.A. and Thomas, R.H. (eds.), Chapman Hall, London, 1997, pp. 139-153.

Waloßek, D. and Müller, K.J., Early arthropod phylogeny in light of the Cambrian "Orsten" fossils. In: Arthropod Fossils and Phylogeny, Edgecombe, G.D. (ed.), Columbia University Press, New York, 1998, pp. 185-231.

Waloßek, D. and Maas, A., The evolutionary history of crustacean segmentation: a fossil-based perspective. Evol. Devel., 7 (2005) 515-527.

Watson, D.I., O’Riordan, R.M., Barnes, D.K.A. and Cross, T., Temporal and spatial variability in the recruitment of 
barnacles and the local dominance of Elminius modestus Darwin in SW Ireland. Est. Coast. Shelf Sci., 63 (2005) 119-131.

Webster, S.G. and Dircksen, H., Putative molt-inhibiting hormone in larvae of the shore crab Carcinus maenas L.: an immunocytochemical approach. Biol. Bull., 180 (1991) 65-71.

Williamson, D.I., Larval morphology and diversity. In: Embryology, Morphology and Genetics, The Biology of Crustacea, Vol. 2, Abele, L.G. (ed.), Academic Press, New York, 1982, pp. 43-110.

Williamson, D.I., Larvae and Evolution - Toward a New Zoology. Chapman Hall, New York, 1992.

Williamson, D.I., Larval transfer in evolution. In: Horizontal Gene Transfer, Syvanen, M. and Kado, C.I. (eds.), Chapman Hall, London, 1998, pp. 436-453.

Williamson, D.I., Larval transfer and the origins of larvae. Zool. J. Lin. Soc., 131 (2001) 111-122.
Williamson, D.I. and Rice, A.L., Larval evolution in the Crustacea. Crustaceana, 69 (1996) 267-287.

Young, C.M., Novelty of supply side ecology. Science, 235 (1987) 415-416.

Zaklan, S.D., Review of the family Lithodidae (Crustacea: Anomura: Paguroidea): distribution, biology, and fisheries. In: Crabs in Cold Water Regions: Biology, Management, and Economics, Paul, A.J., Dawe, E.G., Elner, R., Jamieson, G.S., Kruse, G.H., Otto, R.S., Sainte-Marie, B., Shirley, T.C. and Woodby, D. (eds.), University of Alaska Sea Grant College Program AKSG-02-01, Fairbanks, AK, USA, 2002, pp. 751-845.

Zeleny, C., Compensatory regulation. J. exp. Zool., 2 (1905) 1-102.

Zeng, C.S., Li, S.J. and Zeng, H., Occurrence of additional zoea-VI larvae in the mud crab, Scylla paramamosain (Estampador), reared in the laboratory. Hydrobiologia, 529 (2004) 49-58. 